\title{
The Columbia River Basalt
}

Group in the Spokane

Quadrangle, Washington,

Idaho, and Montana

$\begin{array}{lllllllllllllllllllllllll}\text { G E O L O G I C A L } & \text { S U R V E Y } & \text { B U L L L E T } & \text { I } & \text { N } & 1 & 4 & 1 & 3\end{array}$
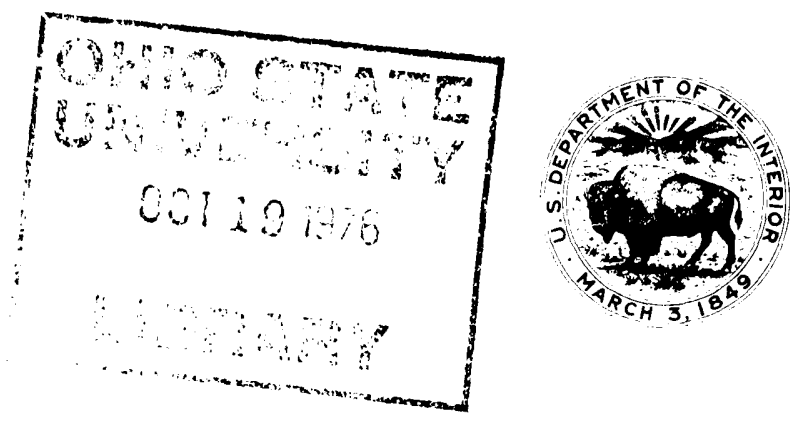



\section{The Columbia River Basalt}

Group in the Spokane

Quadrangle, Washington,

Idaho, and Montana

$\rightarrow$ By A. B. GRIGGS

With a section on PETROGRAPHY

By D. A. SWANSON

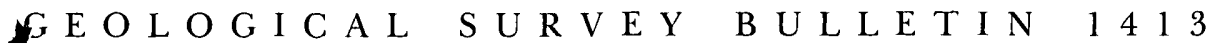

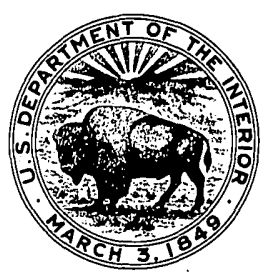

JNITED STATES GOVERNMENT PRINTING OFFICE, WASHINGTON : 1976 


\title{
UNITED STATES DEPARTMENT OF THE INTERIOR
}

\author{
THOMAS S. KLEPPE, Secretary
}

\section{GEOLOGICAL SURVEY}

V. E. McKelvey, Director

Library of Congress Cataloging in Publication Data

Griggs, Allan B.

The Columbia River Basalt Group in the Spokane quadrangle, Washington, Idaho, and Montana.

(Geological Survey Bulletin 1413)

Bibliography: p. 37-39.

Supt. of Docs. No.: I $19.3: 1413$

1. Basalt-Washington (State)-Spokane region. 2. Geology-Washington (State)-Spokane regic I. Swanson, Donald A., joint author. II. Title. III. Series: United States Geological Survey Bulletin 1413.

QE75.B9 no. 1413 [QE462.B3] $557.3^{\prime} 08 \mathrm{~s}\left[552^{\prime} .2\right]$ $76-608142$

For sale by the Superintendent of Documents, U. S. Government Printing Office Washington, D. C. 20402

Stock Number 024-001-02846-8 


\section{CONTENTS}

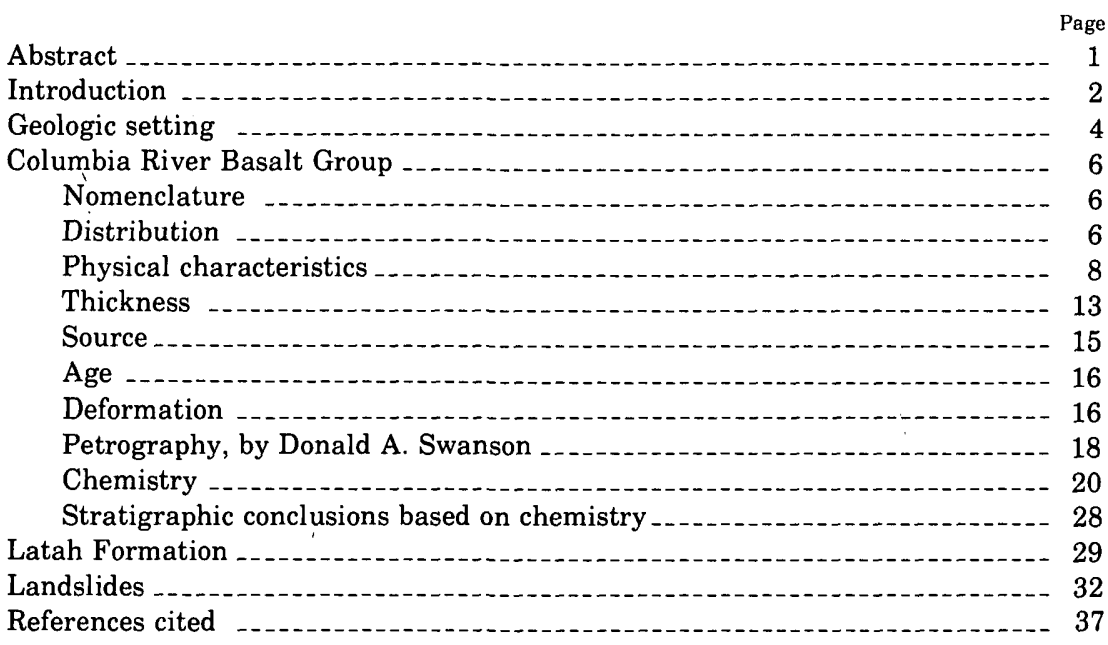

\section{ILLUSTRATIONS}

Plate 1. Maximum extent of the Columbia River Basalt Group in the Spokane quadrangle, Washington and Idaho

Figure 1. Index map of adjacent parts of Washington, Idaho, and Montana showing the location of the Spokane quadrangle _................. 2

2. Pillow-palagonite complex consisting principally of pillows _..._-_. 10

3. Pillow-palagonite complex in roadcut 1 mile southwest of Malden, Wash., in southwest part of the quadrangle _................ 11

4. Roadcut 900 feet $(275 \mathrm{~m})$ long just north of O'Gara Bay, Coeur d'Alene Lake, showing a sedimentary interlayer that has been invaded by a basalt flow which most likely advanced from southwest to northeast _. 12

5. Silica variation diagram of basalts from the Spokane quadrangle $\quad$-_ 26

6. Sections through drill holes showing relation between basalt flows and interlayered sedimentary rocks of the Latah Formation in the Spokane area

\section{TABLES}

TABLE 1. Nomenclature of the Columbia River Basalt Group in the Spokane quadrangle 
TABLE 2. Radiometric potassium-argon ages of basalts in the Spokane quadrangle

3. Summary of petrographic data for chemically analyzed specimens _- 19

4. Chemical analyses of basalt specimens from the Spokane quadrangle 


\title{
THE COLUMBIA RIVER BASALT GROUP IN THE SPOKANE QUADRANGLE, WASHINGTON, IDAHO, AND MONTANA
}

\author{
By A. B. GRIGGS
}

\section{ABSTRACT}

The Columbia River Basalt Group underlies most of the western half of the $6,400 \mathrm{mi}^{2}$ $\left(16,500 \mathrm{~km}^{2}\right)$ of the Spokane $1^{\circ} \times 2^{\circ}$ quadrangle and forms the northeast corner of the Columbia Plateau. Of its two formations, the Picture Gorge Basalt and the overlying Yakima Basalt, only the Yakima is exposed in the quadrangle. Remnants of basalt also are found well up the stream valleys in the mountainous country to the east and north. Prebasalt topography had greater relief than that of today, but drainage patterns were much the same as observed now. The major channels have been largely exhumed in the eastern part and north edge of the quadrangle. Pillow-palagonite complexes, formed where lava flowed into bodies of water, also are numerous in the peripheral part of the plateau; commonly these show directions of lava flow by foreset arrangement of flow components.

Lacustrine and stream sedimentary layers are interbedded with the flows throughout the marginal part of the plateau, where they accumulated behind dams of the advancing basalt flows. Collectively the sedimentary beds have been called the Latah Formation. In this paper the Latah is restricted to those consolidated sedimentary deposits associated with basalt within the drainage of the Spokane River.

Ancient valleys along the eastern margin of the Columbia Plateau were filled to a depth of $1,000 \mathrm{ft}(300 \mathrm{~m})$ or more by interlayered basalt flows and sediments. Toward the west edge of the quadrangle the basalt pile could be two or three times as thick.

Regional subsidence of the entire region toward the west and southwest, partly contemporaneous and partly subsequent to the extrusion of the basalt, is the only observable deformation in the northeastern corner of the Columbia Plateau.

As in other recent investigations of basalts in the Columbia Plateau, a stratigraphic sequence based largely on the composition of the flows was feasible. Only the lower two of three informally named stratigraphic units, the lower and middle Yakima basalts, are exposed in the Spokane quadrangle. By far the largest amount exposed belongs to the middle Yakima basalt, which forms a capping veneer of from two to four flows and in some places more. However, the greatest volume of the basalt underlying the quadrangle must belong to the lower Yakima basalt, although only a few flows of this type are exposed in some of the more deeply incised valleys.

Landslides involving the interlayered basalt and sedimentary rock are numerous in the peripheral part of the plateau. They occurred along the steep valley walls, where failure generally was initiated within the weak sedimentary layers. Most landslides seem stabilized by the subsequent shoring effect of glacial debris or valley fill. 


\section{INTRODUCTION}

The Spokane quadrangle, between lat $47^{\circ}$ and $48^{\circ}$ and long $116^{\circ}$ and $118^{\circ}$, lies about half in Washington and half in Idaho, with the very northeast corner in Montana (fig. 1). This area totals more than $6,400 \mathrm{mi}^{2}\left(16,500 \mathrm{~km}^{2}\right)$ and includes both the northeast corner of the Columbia Plateau and part of the foothills and mountains of the northern Rocky Mountains. These mountains rim the plateau on the north and east. The plateau, which occupies much of the west half of the quadrangle, slopes gently southwestward from 2,500 to $2,800 \mathrm{ft}$ $(760-850 \mathrm{~m})$ elevation around the northeast margin to summit elevations between 1,800 and $2,000 \mathrm{ft}(550$ and $610 \mathrm{~m})$ in the southwest corner. The westward-flowing Spokane River and its tributaries, part of which empty into and flow through Coeur d'Alene Lake, drain most of the quadrangle. Several small streams along the southeast margin and southwest corner all drain into the Snake River. The mountains to the east and north have as much as $3,500 \mathrm{ft}(1,070 \mathrm{~m})$ of relief with the highest ridge crests slightly over $6,000 \mathrm{ft}(1,630 \mathrm{~m})$.

The geologic map of the Spokane quadrangle I-768 (Griggs, 1973) is an essential adjunct to this report. Although partly obscured by

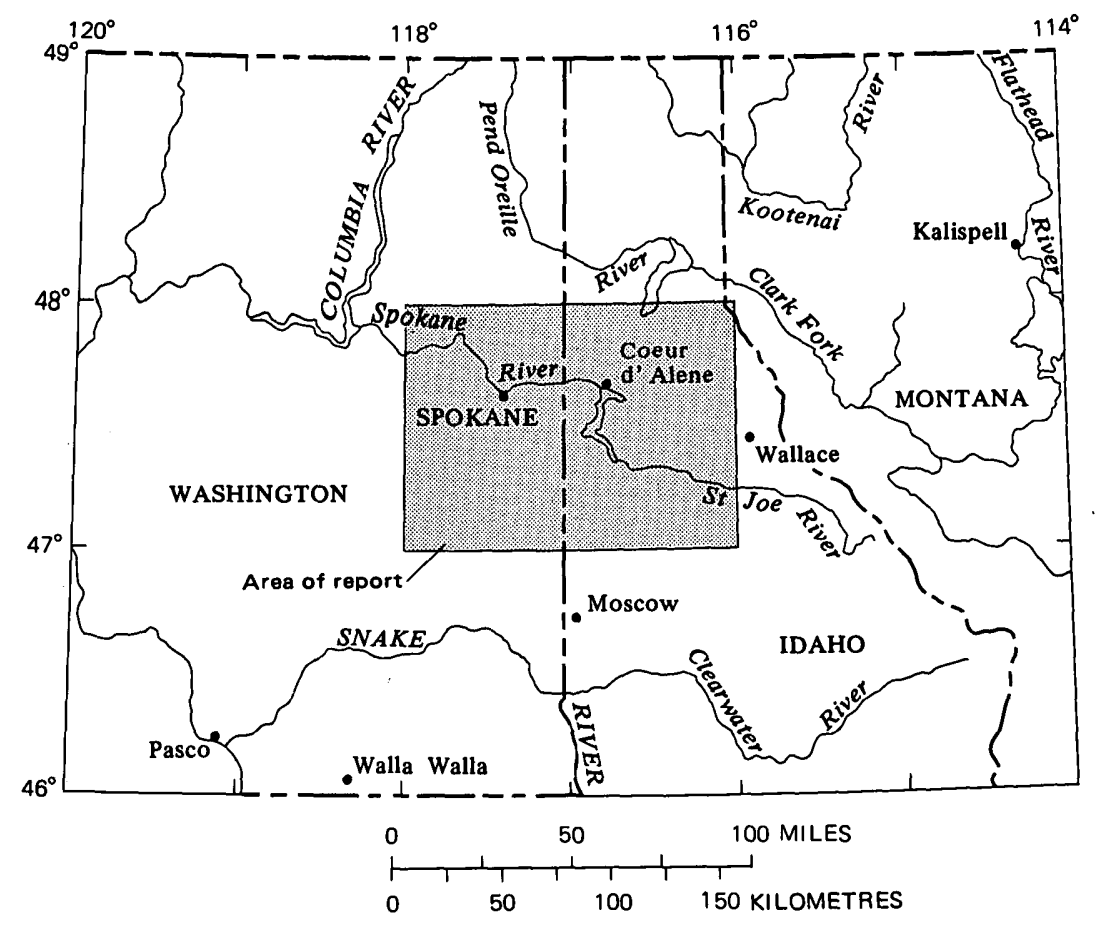

Figure 1.-Index map of adjacent parts of Washington, Idaho, and Montana showing the location of the Spokane quadrangle. 
surficial deposits, the original extent of the basalt is well delineated on it, and the amount subsequently eroded also is quite evident.

Tertiary flood basalts, comprising the Columbia River Basalt Group, interlayered sedimentary deposits of the Latah Formation, and a capping of Pleistocene loess of the Palouse Formation underlie more than half of the quadrangle, and eroded remnants of these flows still remain well up into the valleys of the mountains. In an early investigation Russell (1893) called these plateau basalts of eastern Washington and Oregon the "Columbia lavas"; he later amended this name to "Columbia River lavas." Pardee and Bryan (1926), who made the first study in the Spokane area, preferred a local name and described what they considered correlative with the plateau basalts as "rim rock" flows. They considered the basalt that they found below the rim rock to be considerably younger intracanyon flows, which they called "valley" flows. The interlayered relations between the basalt and lacustrine deposits at several places within the Spokane quadrangle were described by Kirkham (1926) and Kirkham and Johnson (1929). Remnants of the basalt in Kootenai County, Idaho, were described briefly by Anderson (1940) under the name Columbia River Basalt. The relation between the Columbia River Basalt and the clay deposits along the eastern periphery of the plateau was described by Hosterman, Scheid, Allen, and Sohn (1960) and Hosterman (1969). Weis (1968) briefly mentioned that remnants of the basalt of the Columbia River Group occur in the Greenacres quadrangle just east of Spokane. Several potassium-argon ages of basalts collected in the Spokane area and the eastern part of the plateau indicate that the outpouring of these basalts occurred about 16-13 m.y. (million years) ago (Gray and Kittleman, 1967; Watkins and Baksi, 1974). Potassium-argon ages outside this range reported by Gray and Kittleman (1967) are considered incorrect on the basis of stratigraphic evidence and the other potassium-argon ages.

The basalts in the drainages of St. Joe and St. Maries Rivers have been discussed in a number of reports. Several small remnants of basalt that lie high above the floor of the St. Joe valley and at the east edge of the Spokane quadrangle were mapped by Pardee (1911) and again by Umpleby and Jones (1923). Wagner (1949) correlated them with the Columbia River Basalt. Dort (1967) considered these remnants as well as the more widespread occurrences downstream to be separate from and younger than the Columbia River Basalt and called them the St. Joe Valley Basalt of latest Pliocene or early Pleistocene age. Bishop (1969) separated the basalt in the St. Joe and St. Maries River valleys into three stratigraphic units; he included the lower two in the Columbia River Group and, in common with Dort, considered the upper group of flows as younger and of local origin. 
Evidence presented in this paper indicates that all these flows belong to the Columbia River Basalt Group as defined herein.

Reconnaissance geologic mapping of the quadrangle spanned the period from 1961 through 1969. The plateau area of the quadrangle in which most of the basalt occurs was mapped during the 1961 and 1962 field seasons. The remaining areas underlain by basalt were covered during parts of the field seasons of 1963, 1967, 1968 and 1969. Field assistants during these years were Robert K. Smith, Jere M. Hagen, Edwin Stump, Rauno Pertu, and Robert J. Ries. Geologic maps of the Greenacres and Mount Spokane 15-minute quadrangles were kindly furnished by Paul Weis and A. E. Weissenborn, who investigated these quadrangles separately.

Discussions of several of the aspects of the basalts in the quadrangle with $\mathrm{D}$. A. Swanson are gratefully acknowledged. The rock analyses were made by Paul Elmore, Sam Botts, Lowell Artis, Gillison Chloe, and Hezekiah Smith. The semiquantitative spectrographic analyses were made by Harry Bastron, Ivan Barlow, J. L. Harris, and Chris Heropoulos.

\section{GEOLOGIC SETTING}

A fairly accurate estimate of the distribution of basement rocks now concealed beneath the flood basalts of the Spokane quadrangle can be made by extrapolation from the many occurrences of older rock that protrude above the basalt surface. The general configuration of the prebasalt surface can be reconstructed fairly well, and the span of time involved during this great outpouring of lava can be estimated rather closely.

Much of the buried basement consists of Precambrian sedimentary rocks of the Belt Supergroup that make up most of the hills and ridges protruding above the basalt surface well out into the northeastern corner of the Columbia Plateau (Griggs, 1973). Paleozoic sedimentary rocks form a minor amount of the exposed basement along the west margin near the north edge of the map area. These rocks have been intruded by many widespread granitic plutons of Mesozoic and Tertiary age. Some of these plutons have coalesced into a batholith in and beyond the northwest corner of the map area. Mafic dikes and sills of both Precambrian and Mesozoic to Tertiary age are numerous but total only a small percentage of the basement rock. Some older Tertiary andesitic to dacitic volcanic rocks and associated shallow intrusive rocks form a comparably small percentage of the basement. The volcanic rocks lie on the eroded surfaces of some of the granitic rocks north of the area underlain by the Columbia River Basalt Group. The Belt Supergroup has been folded and faulted as a result of several crustal disturbances, and all its rocks are somewhat metamorphosed. 
At the close of the crustal unrest in early Tertiary time, much of this country was mountainous, with relief at least $1,000 \mathrm{ft}(300 \mathrm{~m})$ more than today, and was actively being eroded. Logs of the LatahTexas and Davenport wells in the Spokane area (Pardee and Bryan, 1926) show more than $1,000 \mathrm{ft}(300 \mathrm{~m})$ of fill, including lake and stream sediments and basalt, below the present valley surface. In the Spokane valley 25 miles to the east, a gravity survey (D. L. Peterson, written commun., 1969) indicated a similar thickness of relatively unconsolidated valley fill. Here, the top several hundred feet of fill is Pleistocene glacial outwash, but the remainder is most likely material similar to that found in the wells to the west. A profile diagram by Hobbs, Griggs, Wallace, and Campbell (1965) shows that these same relations extend up the Coeur d'Alene River and its South Fork, which flows on fill for more than $100 \mathrm{mi}(160 \mathrm{~km})$ east of Spokane (70 $\mathrm{mi}(110 \mathrm{~km})$ air line). The St. Joe River system to the south also flows on fill for many miles. Part of this aggradation has resulted from the formation of Coeur d'Alene Lake by a dam of glacial outwash in Pleistocene time, but this was a superficial feature superimposed on the earlier material that accumulated behind the dams of basalt flows.

The drainage systems of the Coeur d'Alene and St. Joe Rivers were virtually the same at the beginning of the outpouring of the basalt as they are today. Remnants of gravel fill on terraces and capping ridges along the South Fork and the main channel of the Coeur D'Alene River closely outline the position and height of this valley at the time of maximum aggradation behind the basalt. The present exhumed valley differs in position from the older channel only locally in places where the old gravel-filled channel is separated from the present valley by a rib of bedrock.

The St. Joe valley differs in that much of the fill consisted of basalt, as indicated by the many remnants perched on the valley walls for almost $40 \mathrm{mi}(65 \mathrm{~km})$ upstream from the mouth of St. Joe River at Coeur d'Alene Lake. The axis of the prebasalt valley from St. Maries to a point about $12 \mathrm{mi}(20 \mathrm{~km})$ east was located about $2 \mathrm{mi}$ south of the present valley. The old buried valley now lies under a broad flat almost $6 \mathrm{mi}$ wide that is almost entirely underlain by basalt.

The old and present courses of the Spokane valley virtually coincide across the entire quadrangle. The ancient Clark Fork likely flowed south and west through Pend Oreille Lake and Rathdrum Prairie into the Spokane valley, where it joined the west-flowing Spokane River. This contrasts with the modern Clark Fork which flows west and then north out of Pend Oreille Lake (fig. 1). In prebasalt time the St. Joe and Coeur d'Alene Rivers may have joined and flowed southwestward; their waters now course northward through 
Coeur d'Alene Lake and into the Spokane River.

The configuration of the eastern part of the Spokane quadrangle in prebasalt time differed from the modern topography only in having distinctly greater relief. This topography probably extended into the western part of the quadrangle, where it was progressively buried by basalt flows after volcanism began. Subsidence related to extrusion caused the depth of burial to become progressively greater to the southwest, and there even the tops of the ridges have been covered by the upper flows. A paleoslope to the west in prebasalt time must also have been a contributing factor in this general diminishing of topographic relief in that direction. An exploratory drill hole some $35 \mathrm{mi}$ $(50 \mathrm{~km})$ west of the southwestern margin of the quadrangle went through 4,865 $\mathrm{ft}(1,497 \mathrm{~m})$ of basalt and sedimentary rock before reaching crystalline basement, indicating $4,000 \mathrm{ft}(1,200 \mathrm{~m})$ or more of subsidence concurrent with and subsequent to the basalt extrusion. Had comparable subsidence taken place in the mountainous Spokane area, even the higher summits would have been buried under the lavas and related sediments.

\section{COLUMBIA RIVER BASALT GROUP}

\section{NOMENCLATURE}

The term Columbia River Basalt had long been applied to extrusive volcanic rocks of the Columbia Plateau that are predominantly basaltic. This term was raised by Waters $(1961$, p. 607) to group rank, the Columbia River Group, when these basalts were subdivided into the Picture Gorge Basalt and the overlying Yakima Basalt. However, the later inclusion into the group of interfingering largely nonbasaltic formations, such as the Mascall Fromation, a fluvial sedimentary deposit (Thayer and Brown, 1966), has seriously modified Waters' original definition of the group. Reference to only its basalt now required the awkward phrase "basalt of the Columbia River Group."

This problem in definition and nomenclature was discussed in late 1974 by Survey and non-Survey volcanologists, petrographers, and stratigraphers, and it was generally agreed to exclude formations that are largely nonbasaltic. This usage is followed in this report, and the name Columbia River Group is here redesignated the "Columbia River Basalt Group" (table 1) to reflect this restricted usage.

\section{DISTRIBUTION}

A maximum of almost $4,000 \mathrm{mi}^{2} \cdot\left(10,400 \mathrm{~km}^{2}\right)$, over 60 percent, of the Spokane quadrangle was covered by flows of the Columbia River Basalt Group at the end of their period of extrusion (pl. 1). Subsequent erosion within the major stream courses has removed the 
TABLE 1.-Nomenclature of the Columbia River Basalt Group in the Spokane quadrangle

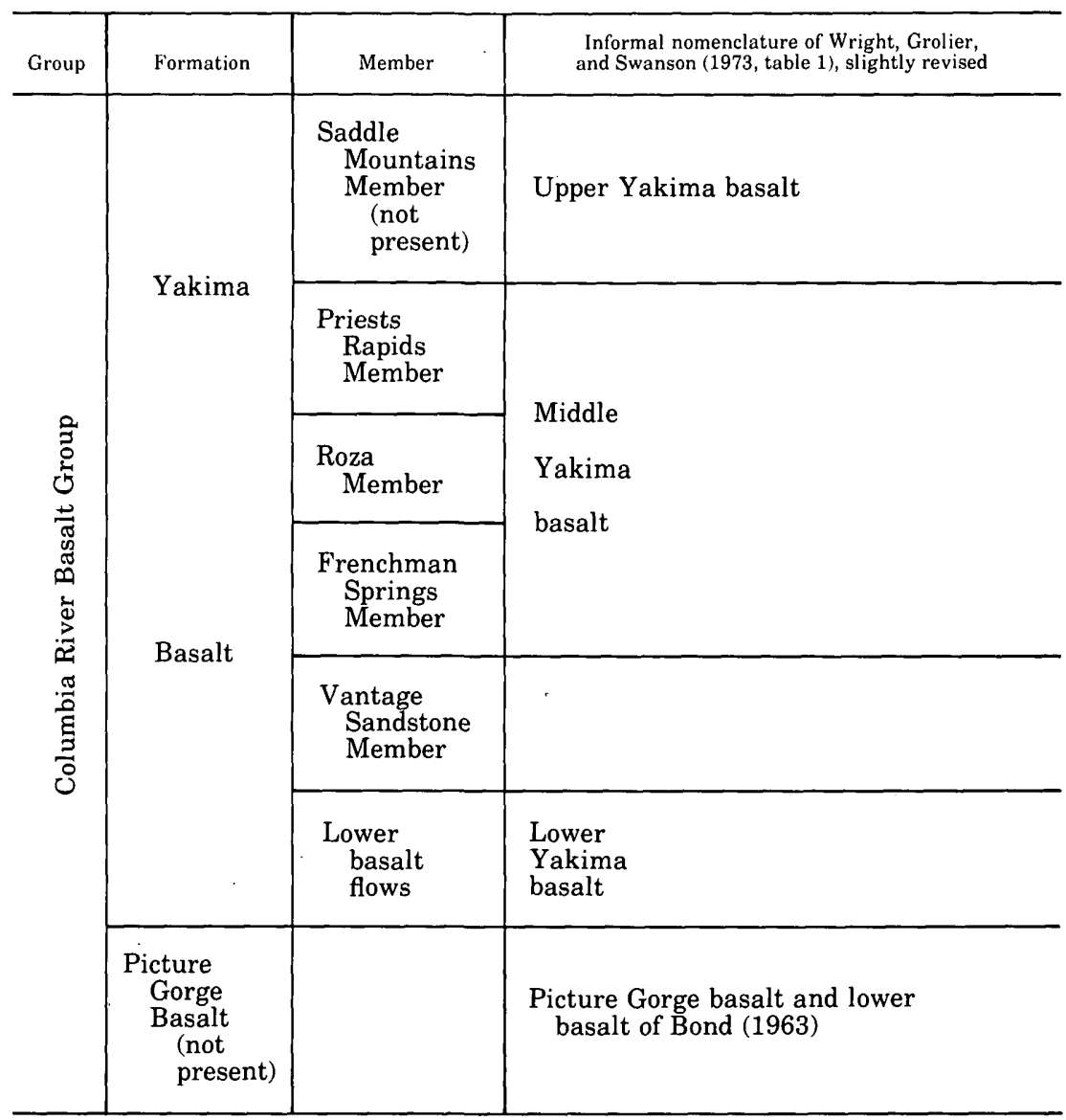

basalt cover from an estimated $700 \mathrm{mi}^{2}\left(1,925 \mathrm{~km}^{2}\right)$. Approximately half of the quadrangle is still underlain by basalt, including almost all of the southwest quarter, a large part of the northwest quarter, and many patchy areas along major stream valleys in the mountainous east half of the quadrangle.

Loess deposits that make up the Palouse Formation, of Pleistocene age, mantle much of the basalt in the plateau area. They not only cover the basalt but also the lower slopes of the hills and ridges of older rock that protrude above the basalt. Thus the marginal contacts of the uppermost basalt flow are almost everywhere concealed. The loess is as much as $250 \mathrm{ft}(75 \mathrm{~m})$ thick near the southwest corner of the map (Ringe, 1970); it thins to the north and east and at the margins of the plateau is only a few feet to slightly more than $50 \mathrm{ft}$ $(15 \mathrm{~m})$ thick. 
Parts of the loess mantle were stripped by the spectacular Spokane Flood (Bretz, 1959) to produce the well-known channeled scabland. Toward the east, this enormous flood breached several low divides in the vicinity of Spokane and coursed southwestward across the Columbia Plateau. There it left only islands of the loess in a channel as much as $20 \mathrm{mi}(32 \mathrm{~km})$ across. Not only was the loess removed but much of the upper flow, and sometimes more than the upper flow, also was scabbed out of the channel. At places the flood gouged out enormous potholes as much as several flows deep that now remain as elongate lakes dotting the scabland. Except for this scabbed area and along a few major stream courses, outcrops of basalt are scattered, small, and relatively few because of the completeness of the loess mantle over the southwest part of the quadrangle (Griggs, 1973).

\section{PHYSICAL CHARACTERISTICS}

The Columbia River Basalt Group in the Spokane quadrangle is typically a gray to almost black fine-grained to aphanitic basalt. Except at the top or bottom of a flow it is commonly dense, although many flows exhibit patchy diktytaxitic texture. The more holocrystalline rock everywhere contains these scattered openings about 1 $\mathrm{mm}$ across. These more holocrystalline rocks also are weathered brownish gray owing to their greater permeability. Most vesicularity is restricted to the top and bottom of flows. Only a relatively narrow selvage at the base of a flow is vesicular, but such a texture may extend through many feet at the top. A few. vesicles usually less than $1 \mathrm{~cm}$ in diameter may be scattered throughout a flow. If the top has not been too weathered or eroded, it is noticeably scoriaceous. A few flows contain scattered honey-colored prismatic phenocrysts of plagioclase as much as $1 \mathrm{~cm}$ long.

Individual flows range in thickness from zero, where they impinge on a sloping surface, to as much as $200 \mathrm{ft}(60 \mathrm{~m})$. Most, however, are between 50 and $100 \mathrm{ft}$ plus $(15-30 \mathrm{~m})$ thick. The flows have welldeveloped columnar joints at the base, but these change abruptly to irregular or poorly developed joints above. These segments of the flows are termed the colonnade and entablature respectively (Mackin, 1961). The colonnade almost everywhere makes up considerably less than half the flow, commonly a third or even less. Most columns range from 4 to $10 \mathrm{ft}(2.5-3 \mathrm{~m})$ across. The columns commonly are cut by horizontal to curved cross joints. The entablature is cut by randomly oriented hackly fractures that separate the rock into irregular blocks. In some flows well-developed columns may make up about a third of the top part of the flow, forming an upper colonnade. In other flows a repetition of hackly to columnar jointing may give the entablature a tiered arrangement. Thus a variety of jointing patterns set 
the entablature off from the well-developed columns in the basal colonnade.

No attempt has been made to follow out single flows or groups of flows, as has been done successfully by a number of investigators (Mackin, 1961; Bingham and Walters, 1965; Bingham and Grolier, 1966; Schmincke, 1967a; Grolier and Bingham, 1971) to the southwest in central Washington. One of the most persistent of the units found there, the Roza Member, has apparently been traced into the southwest corner of the Spokane quadrangle (D. A. Swanson, oral commun., 1973) where it is represented by a single flow that pinches out near Bonnie Lake. It has been estimated to cover over $20,000 \mathrm{mi}^{2}$ $\left(53,000 \mathrm{~km}^{2}\right)$ (Bingham and Grolier, 1966). Similarly persistent units are expectable, and one may be represented by a prominent basal colonnade with unusually large and symmetrical columns $6-10 \mathrm{ft}$ $(1.8-3.0 \mathrm{~m})$ in diameter that is found at many scattered localities in the scabland area southwest of Spokane. Bishop (1969) also described several widespread flows in the drainages of St. Joe and St. Maries Rivers.

Pillow-palagonite complexes are common near the margin of the plateau. In this setting they have resulted from fluid lava invading a body of water or a boggy marshland. Much of the hot lava exploded on contact with water or wet unconsolidated sediments and formed a rubbly mass of granular sideromelane that later was palagonitized. The lava-water interaction was at times much less explosive, and lava separated into bulbous, roughly ellipsoidal, and fairly discrete pillows or thin-sheeted layers with glassy selvages. Mixtures of the sideromelane breccia and pillows form the resulting pillowpalagonite complexes. Their character, setting, and origin on the plateau have been well described by Fuller (1931).

Where relations are well exposed in the Spokane quadrangle, these complexes generally can be seen to form the basal part of a flow. These may amount to only a thin interlayer of glassy breccia or illformed pillows but at other exposures may make up the major part of a flow. A few complexes are $75 \mathrm{ft}(23 \mathrm{~m})$ or more thick. One such complex crops out above the Burlington Northern Railroad tracks across the river northwest of Spokane (figure 2). The interface between the pillow-palagonite complex and the unbroken and unaltered flow above marks the top of the invaded water. The complexes generally consist of a mixture of palagonitic breccia and pillows, but outcrops consisting only of pillows or of a palagonitic breccia or even sideromelane tuff are not rare. Irregular sheeted masses of lava may also be included within a complex (figure 3 ). Several discontinuous outcrops of pillow lavas at altitudes near $2,850 \mathrm{ft}(870 \mathrm{~m})$ extend for almost $10 \mathrm{mi}(16 \mathrm{~km})$ along the St. Maries River valley; these proba- 


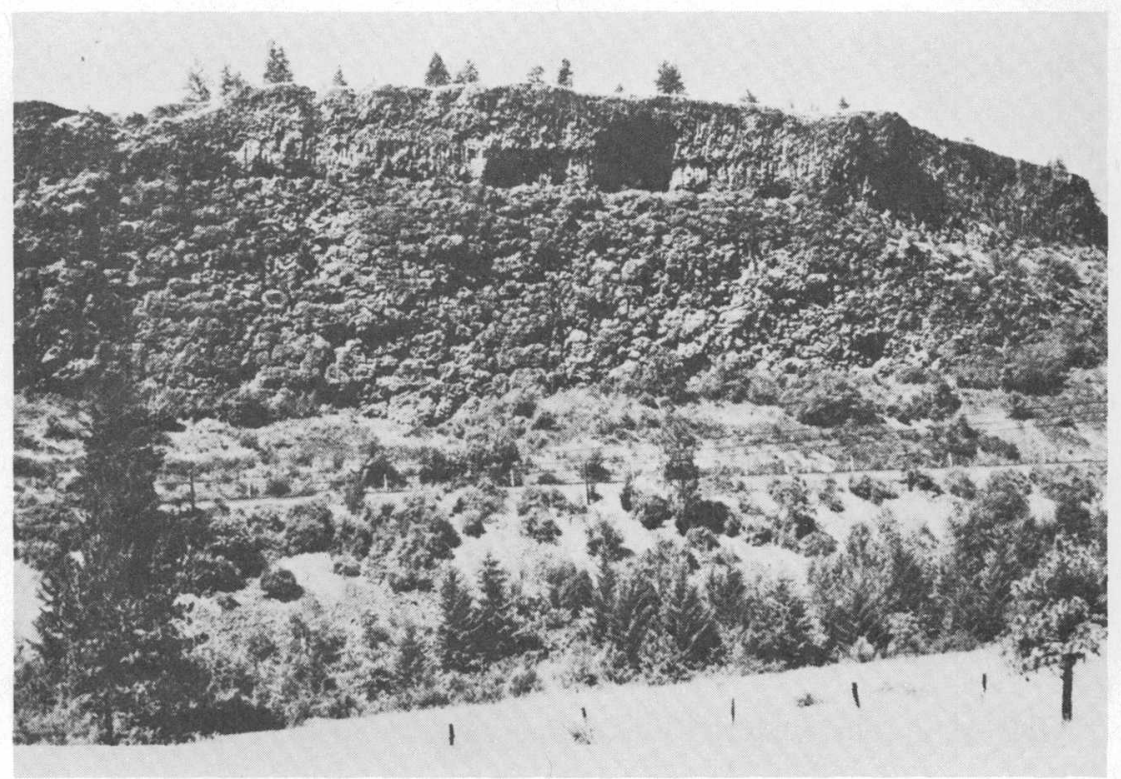

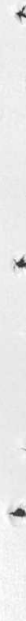

Figure 2.-Pillow-palagonite complex consisting principally of pillows.

bly all belong to the same flow and indicate how extensive these complexes may be.

Many scattered occurrences of pillow-palagonite complexes have been observed within the quadrangle. Many more probably have escaped attention because of the general lack of exposures or the concealment of the basal part of flows by rubble or talus. Complexes are most common near the margin of the plateau or in the remnants of basalt in the valleys tributary to the plateau. Thus most have been seen in the vicinity of Spokane and west along the south edge of the Spokane River valley, along the eastern shore of Coeur d'Alene Lake, and within the drainage basins of the St. Joe and St. Maries Rivers. This is the expected locale for their occurrence, as the greatest number of ponds and lakes must have been formed here behind lava dams as the plateau grew and lava flows advanced eastward.

Although an occasional pillow-palagonite complex lies directly on another flow, almost all those observed cap a sedimentary interlayer. At all such places the sedimentary rocks show features that suggest the sediments were unconsolidated. At some places, wisps to lenses of the sedimentary rocks are incorporated within the complex, as a result of churning up of the upper surface of the sediments by the advancing lava or by its explosive disruption. A much greater 


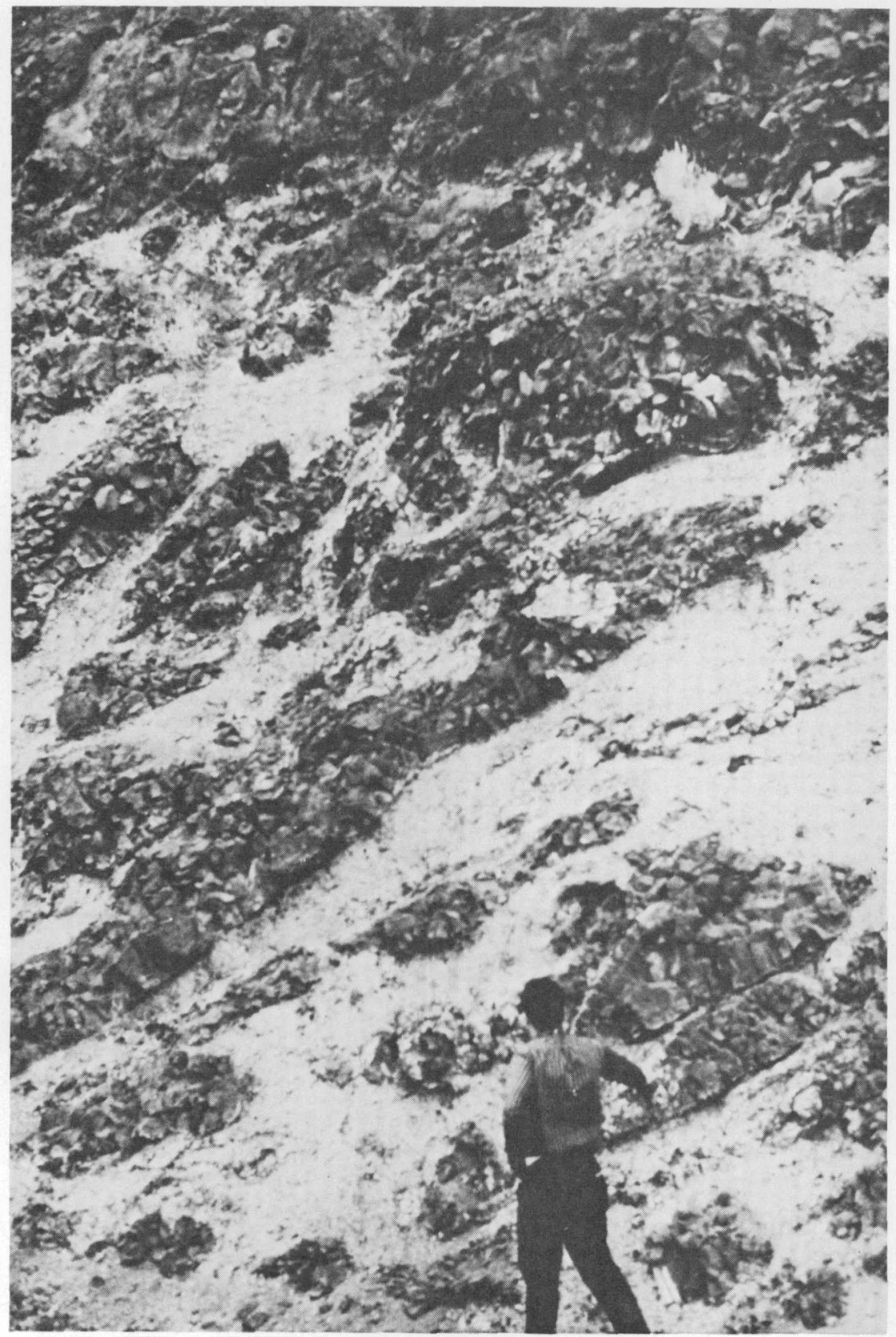

Figure 3. -Pillow-palagonite complex in roadcut 1 mile southwest of Malden, Wash., in southwest part of the quadrangle. 
amount of disturbance than usual is exposed in a roadcut almost 4.5 mi $(7 \mathrm{~km})$ southeast of Harrison, Idaho, just above the east shore of Coeur d'Alene Lake (fig. 4). These disrupted blocks of sedimentary rocks, a dikelike apophysis, pépérite tongues, and a complex of pillows and palagonite breccia are associated with a sedimentary interlayer about $35-50 \mathrm{ft}(10-15 \mathrm{~m})$ thick. The pépérite (Schmincke; 1967b), a mixture of fragmented lava, much of it palagonitized sideromelane, and broken and shattered sedimentary rock, is most logically a result of hot fluid lava invading wet unconsolidated sediments. The tongues of pépérite may extend back into solid lava similar to the dikelike body just north of them. The pillows with intermixed sediments at the contact between the rotated sedimentary rocks and basalt also point to a surficial invasion. The next roadcut a few hundred feet to the north exposes a pillow-palagonite complex that, because of its relative position, must be the basal part of the flow that disrupted the upper part of the sediment interlayer. Thus it appears that the flow had invaded a lake floored by the sediments.

Several structures that are useful in determining direction of flow for flood basalts like those of the plateau have been described by

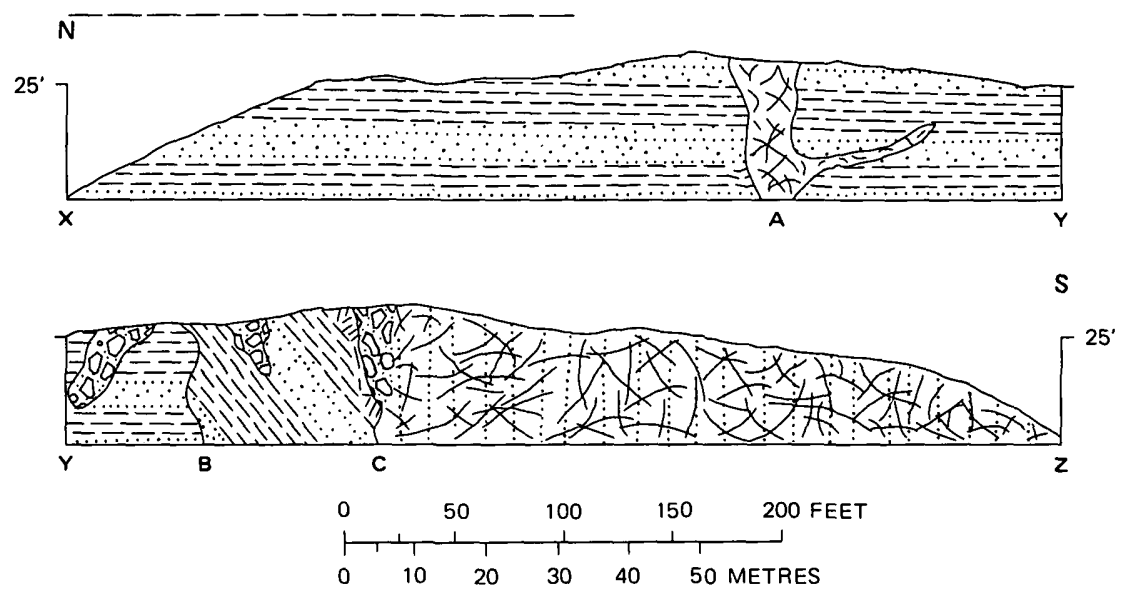

Figure 4.- Roadcut $900 \mathrm{ft}$ (275 m) long just north of O'Gara Bay, Coeur d'Alene Lake, showing sedimentary interlayer that has been invaded by a basalt flow which most likely advanced from southwest to northeast. Surface of sedimentary rocks may have been somewhat irregular owing to interflow erosion. Dashed line over north end of section is estimated top of the sedimentary rocks projected from next cut a few hundred feet to north. From X to B, relatively undisturbed horizontal siltstone and sandstone. At A, a dikelike tongue of hackly basalt with apophysis to the south; sedimentary rocks baked and broken at contact. Above and to the north and south of $\mathrm{B}$, irregular tongues of pépérite extend down into the sedimentary rocks. B-C, a block of sedimentary rock rotated so that it now dips $40^{\circ}$, and with both contacts deformed and broken. C-Z, hackly basalt, noticeably vesicular with some poorly formed pillows at contact at C. Base of sedimentary layer estimated at about $10 \mathrm{ft}$ (3 m) below road level. 
Waters (1960). One of the most useful is the foreset bedding displayed in many pillow-palagonite complexes. The foreset bedding is inclined in the direction of advance, as indicated by direct observations of actively forming complexes in Hawaii (Moore and others, 1973). The bedding may be indefinite where only breccia or tuff make up the complex but becomes much clearer if pillows are within it. The direction of foreset is most sharply defined in those complexes in which sheets of lava flowed down over the front of the lava delta (fig. 3). In places, directions of flow also may be deciphered where the complex consists only of pillows. Some of the pillows cascaded down the front of the flow while still pliable and consequently are draped over the underlying pillows, which give the direction of advance. In deciphering such an exposure, great care must be used to obtain a threedimensional view. Locally a pipe vesicle or spiracle within the upper part of a flow over a complex is bent in the direction of flow.

Flow directions of pillow-palagonite complexes within the quadrangle are shown on plate 1 . The arrow indicates the direction of flow, and the associated number is the elevation where the observation was made. A few localities where a direction could not be deciphered are indicated by only a dot.

\section{THICKNESS}

The Columbia River Basalt Group covers a mountainous terrain, and its thickness varies widely. Relatively accurate estimates of thickness can be made in the eastern half of the Spokane quadrangle where old valleys have been exhumed and much of the basalt and interlayered sedimentary rocks removed. To the west, however, estimates are based largely on data from logs of deep drill holes.

The thickest exposed section of basalt is near the east edge of the Spokane quadrangle at the mouth of Trout Creek, about $20 \mathrm{mi}$ (32 $\mathrm{km}$ ) up the St. Joe River from St. Maries, Idaho. Here over 1,000 ft is intermittently exposed from stream level to the top of the basalt bluffs above. Another section of basalt almost as thick is exposed in many roadcuts about $12 \mathrm{mi}(19 \mathrm{~km})$ west where Highway 95A traverses from valley level to the top of the basalt surface. The total thickness of the first section appears to be exposed, whereas several hundred feet or more of the second section still may be buried under valley fill.

In the Spokane area well logs show that more than $1,000 \mathrm{ft}(300 \mathrm{~m})$ of fill still remains in the prebasalt Spokane valley (Pardee and Bryan, 1926). However, the base of the lowest flow, which was penetrated in the Davenport well near the center of the city, is only $430 \mathrm{ft}$ $(130 \mathrm{~m})$ below valley level and about $1,000 \mathrm{ft}(300 \mathrm{~m})$ below the nearby plateau surface; the remainder of the section below, all 
sedimentary rock, may be partly correlative in age with the basalt or may be entirely older, although still most likely Tertiary in age. From two to four sedimentary layers are interbedded with the basalt flows within this upper interval, and their combined total thickness ranges from 75 to about $300 \mathrm{ft}(23-90 \mathrm{~m})$.

Several deep wells on the plateau south of Spokane cut the base of the basalt at similar depths, but the thickness of sediments interlayered with the basalt is considerably less. Near Spangle, Wash., 15 $\mathrm{mi}(18 \mathrm{~km})$ south of Spokane, a section of basalt more than $700 \mathrm{ft}$ (215 m) thick was cut that contained only several minor soil or sedimentary layers, and the basalt was not bottomed. Another well near Fairfield, Wash., $20 \mathrm{mi}(32 \mathrm{~km})$ southeast of Spokane, penetrated 915 $\mathrm{ft}(279 \mathrm{~m})$ of basalt underlain by $530 \mathrm{ft}(161 \mathrm{~m})$ of sandstone and shale. The thickest sedimentary layer within the basalt was $20 \mathrm{ft}$ (6 m) (Pardee and Bryan, 1926). At Pullman, Wash., almost due south of Spokane and $20 \mathrm{mi}(32 \mathrm{~km})$ beyond the south edge of the quadrangle, a water well drilled almost entirely in basalt intersected crystalline bedrock at $954 \mathrm{ft}$ (290 m) (Foxworthy and Washburn, 1963).

West and southwest of Spokane the basalt thickens, and the number and thickness of sedimentary interlayers decrease. At Davenport, Wash., $7 \mathrm{mi}(11 \mathrm{~km})$ beyond the west edge of the Spokane quadrangle and $35 \mathrm{mi}(56 \mathrm{~km})$ west of Spokane, a city water well was drilled through $720 \mathrm{ft}(220 \mathrm{~m})$ of basalt with a total of only about $25 \mathrm{ft}$ $(7.5 \mathrm{~m})$ of sedimentary rock and soil zones. Near Odessa, Wash., $70 \mathrm{mi}$ $(112 \mathrm{~km})$ southwest of Spokane, an exploratory well was drilled through $4,665 \mathrm{ft}(1422 \mathrm{~m})$ of basalt, underlain by $200 \mathrm{ft}(60 \mathrm{~m})$ of sedimentary rock, before entering quartz latite bedrock. It is not known whether all the basalt and sedimentary rocks cut in this hole are parts of the Columbia River Basalt Group. Brown (1970) believed that part is of older Tertiary age, but the evidence is far from conclusive. By conservative estimate, at least $2,300-3,200 \mathrm{ft}(670-975 \mathrm{~m})$ of Basalt probably is present.

The thickest exposed sections in the western part of the Spokane quadrangle are along Tamarack Creek north of Reardon, where intermittently exposed basalt totals about $600 \mathrm{ft}(180 \mathrm{~m})$ in thickness, and above the east shore of Rock Lake, where more than $500 \mathrm{ft}$ $(150 \mathrm{~m})$ of basalt is almost completely exposed. The base of these exposed sections must be far above the bottom of the basalt. On the basis of the deep drill hole to the west and from exposed sections along the Snake River to the south, a thickness of $1,750-2,500 \mathrm{ft}$ $(530-760 \mathrm{~m})$ of basalt can be estimated conservatively along the southwest edge of the quadrangle. The section could be half again as thick. From this maximum the basalt pile wedges out to the north and east where it abuts older bedrock (pl. 1). 


\section{SOURCE}

Sources for the Columbia River Basalt Group were fissures whose fossil counterparts, dikes in great numbers, have been observed concentrated in swarms in several regions of the Columbia Plateau. This relation was first noted by Lindgren (1901) and reviewed by Waters (1961), who described several different swarms of dikes. The basalt in the Spokane quadrangle probably was derived from the north end of the easternmost of these swarms. This is the Chief Joseph swarm, so named by Taubeneck (1970), who traced it through northeastern Oregon, southeastern Washington, and the adjacent border area of Idaho for a distance of $165 \mathrm{mi}(265 \mathrm{~km})$ The swarm is $50 \mathrm{mi}(80 \mathrm{~km})$ or more wide and trends slightly west of north, as do most of the dikes within it. This swarm is by far the largest and most persistent one in the plateau, and Taubeneck considered 21,000 individual dikes a conservative estimate of the number present. His northernmost dike is exposed in the canyon walls of the Snake River where it turns west through southeastern Washington, about $20 \mathrm{mi}(32 \mathrm{~km})$ short of the south edge of the Spokane quadrangle (fig. 1). Bingham (1970) and Swanson and Wright (1973) reported vents and dikes that are believed to be sources for flows of the Roza Member just a few miles south of the southwest corner of the Spokane quadrangle, and a vent for a younger flow occurs in the town of Palouse, $8 \mathrm{mi}(13 \mathrm{~km})$ south of the quadrangle near the Washington-Idaho border (D. A. Swanson, oral commun., 1972). Compositions of the dikes in the swarm show that many of them probably were feeders for the lower and middle Yakima basalts of Wright, Grolier, and Swanson (1973) and the lower basalt of Bond (1963).

The Chief Joseph swarm probably extends northward into the Spokane quadrangle, but no related dikes or vents were seen during reconnaissance mapping related to this investigation. This probably reflects poor exposures, concealment by the loess of the Palouse Formation, and the reconnaissance nature of the investigation rather than the absence of dikes or vents. A possible center of extrusion is suggested for the area south-southwest of Coeur d'Alene Lake. Flow directions shown by foresets in pillow-palagonite complexes (pl. 1) indicate that flows fanned out from this general area near the center of the quadrangle. Although the number of observations made is not great, their pattern is good, and no notable anomalies are apparent. They particularly indicate flow to the southwest and east. Outcrops of these pillow-palagonite complexes span over $500 \mathrm{ft}(150 \mathrm{~m})$ of section and thus represent several different flows.

Dikelike bodies that intrude the sediments of the Latah Formation in the area around Spokane were described by Pardee and Bryan (1926) as possible feeders of their "rim rock" flows. Inspection of sev- 
eral of these occurrences in the railroad cuts on the west side of Latah Creek near Spokane showed them to be most likely apophyses of flows that had bulldozed their way into the then soft unconsolidated sediments.

\section{AGE}

A number of potassium-argon radiometric ages have been determined on basalt from the Spokane quadrangle (Evernden and James, 1964; J. D. Obradovich, written commun., 1966; Gray and Kittleman, 1967). Those that are considered reasonable are listed in table 2; all these are from localities in the Spokane area. All are middle Miocene in age and fall within a span of about $3 \mathrm{~m}$.y. However, the precision of these determinations is not great enough to separate the older (lower Yakima basalt) from the younger (middle Yakima basalt) assemblage of rocks. In fact, some ages of the lower Yakima ("valley" flows) are younger than ages of the middle Yakima ("rim rock" flows). Holmgren (1970), in attempting to separate flows stratigraphically by radiometric dating in the western part of the basalt field, faced the same problem and concluded "K-Ar dates lack the resolving power to delineate specific Columbia River flows or groups of flows." Most of the flows he dated probably are nearly correlative with some of those in the Spokane area, but they also include some older and certainly some younger (upper Yakima) than those for which ages are reported here. Holmgren's ages span a period of from $12.3 \pm 2.2$ m.y. to $16.9 \pm 1.1$ m.y., with most determinations near the older one. The combined age determinations from the Spokane area bracket slightly more than 5 m.y., but an interval of nearly half of this duration seems more reasonable. This would allow sufficient time for extrusion of the flows, the accumulation of the interbedded sedimentary layers, and formation of soil zones that cover some flows.

\section{DEFORMATION}

The Columbia River Basalt Group in the Spokane quadrangle has been deformed by subsidence and by slight tilting of the entire area to the southwest. This tilted basin is inclined south from the northwest edge of the map area and west from the south-central edge. The top surface of the basalt along these edges is near an elevation of 2,500$2,800 \mathrm{ft}(760-850 \mathrm{~m})$. A continued rise eastward beyond the plateau margin also is evident from a gradual increase in elevation of the tops of basalt remnants scattered above the St. Joe River to the east edge of the map area, where the easternmost of these remnants is at an elevation of almost $3,400 \mathrm{ft}(1,035 \mathrm{~m})$. The top of the basalt is lowest, just over $1,700 \mathrm{ft}(520 \mathrm{~m})$ in elevation, in the southwest corner of the quadrangle. The average westerly inclination across the entire quadrangle is slightly less than $18 \mathrm{ft}(5.5 \mathrm{~m})$ per mile. In a detailed study 
TABLE 2.-Radiometric potassium-argon ages of basalts in the Spokane quadrangle

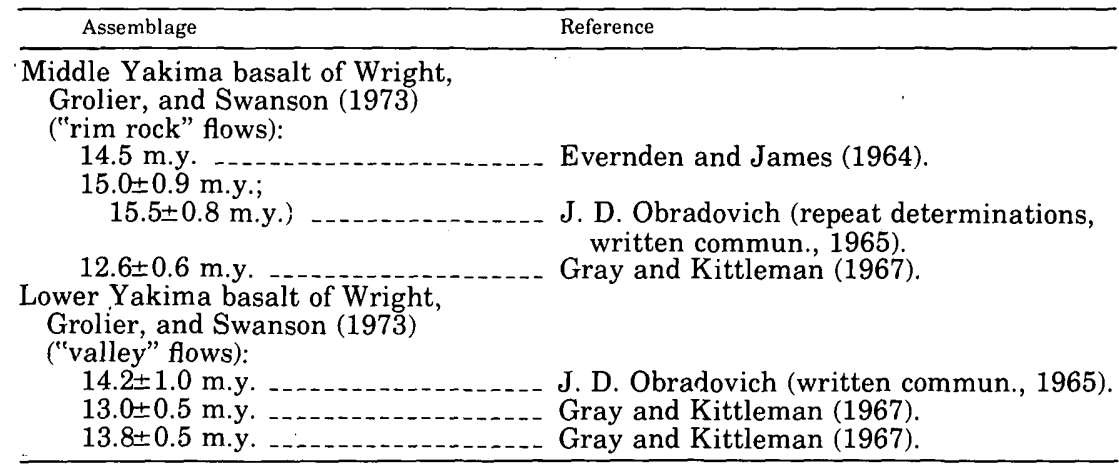

of the topography of the basalt surface of an area that includes part of the southwest corner of the quadrangle, Ringe (1970) concluded that the inclination to the west in the area averaged $15-20 \mathrm{ft}(4.5-6 \mathrm{~m})$ per mile over a distance of about $25 \mathrm{mi}(40 \mathrm{~km})$.

This basining effect within the area of outpouring of the basalt has been recognized since some of the earliest investigations (Lindgren, 1900; Russell, 1901). Some subsidence is believed to have accompanied the extrusion of the basalt. In an investigation of the Clearwater embayment to the southwest, Bond (1963) found flows whose total thickness decreased progressively toward the margin of the basin and other flows that wedged out entirely. Only a relatively small number of flows, from two to four, of the middle Yakima chemical type cap the plateau in the vicinity of Spokane, whereas many more similar flows exist toward the center of the basin. This implies that many flows wedged out toward the margin of the basin or were not voluminous enough to reach the Spokane area. Although this evidence supports a basining during extrusion, the present slope of the top of the basalt also shows that major tilting has taken place since the end of basalt eruptions.

In the area southwest of Spokane, where the waters of the Spokane Flood (Bretz, 1959) stripped loess from the basalts over large areas, three sets of parallel lineaments striking about N. $60^{\circ}$ W. are evident (Griggs, 1973). Each can be traced for 20-25 mi $(32-40 \mathrm{~km})$. The northernmost extends through Cheney to near Medical Lake; the other two are spaced at intervals of from 6 to $8 \mathrm{mi}(10-13 \mathrm{~km})$ to the southwest. The lineaments are sharply evident on aerial photographs; on the ground they are marked by shallow gullies, indentations, or simply lines of trees in otherwise grass-covered areas. It is evident they are the surface expression of narrow. fracture zones along which the broken rock was more easily eroded or which afforded a more favorable environment for trees to grow. No offset was seen along any of the fractures. Trimble (1950) described a similar set 
of fractures with the same northwest trend that lie near the confluence of the Palouse and Snake Rivers about $50 \mathrm{mi}(80 \mathrm{~km})$ to the southwest. There, the gullies are deeply eroded into coulees, and so the pattern stands out in greater relief. All the lineaments appear to have resulted from the same set of forces that must have affected a large region. They most likely reflect some disturbance in the basement below the basalt-most plausibly some horizontal adjustment of relatively small magnitude but widespread effect.

Folds that are so prevalent over much of the rest of the basalt field are not evident within the Spokane quadrangle. No dislocation of the basalt by faulting was found during the mapping. However, several faults of undetermined throw were inferred by Bishop (1969) to offset the basalt southeast of St. Maries, Idaho. A marked topographic lineament can be traced N. $30^{\circ} \mathrm{W}$. across most of the Spokane quadrangle. The lineament is followed by Latah Creek for many miles, but no dislocation of the basalt or the older rocks beneath them has been found along it in the field. Data from the Spokane quadrangle thus support the contention of Newcomb (1970) that the northeast margin of the plateau was relatively stable.

\section{PETROGRAPHY}

By Donald A. Swanson

Table 3 summarizes petrographic data for 19 of the chemically analyzed specimens from the Columbia River Basalt Group. Eight other samples of basalt were examined, with comparable results.

Most of the samples contain a few phenocrysts of plagioclase, and about half the flows also carry phenocrysts of olivine and clinopyroxene. The observed phenocrysts are all so small (less than 2 $\mathrm{mm}$ in diameter) that many may have formed just prior to or after eruption. However, complex intergrowths of plagioclase and pyroxene (rarely olivine) found in some of the flows are probably glomerophyric clots indicative of intratelluric crystallization. A few plagioclase crystals have corroded core zones, and some large olivine crystals have deeply embayed margins and reaction rims of granular clinopyroxene. This evidence also suggests intratelluric crystallization.

Plagioclase phenocrysts are normally zoned, with cores of $\mathrm{An}_{60-70}$ and rims of less than $\mathrm{An}_{50}$; groundmass plagioclase has compositions like the phenocryst rims. Clinopyroxene phenocrysts commonly exhibit intricate zonal relations between augite, subcalcic augite, and pigeonite; the phenocrysts and some microlites have a distinct mauve color in some flows of high $\mathrm{Ti}$ content. Many groundmass olivine crystals exhibit reaction relations with the melt or are partly altered to clay minerals. 


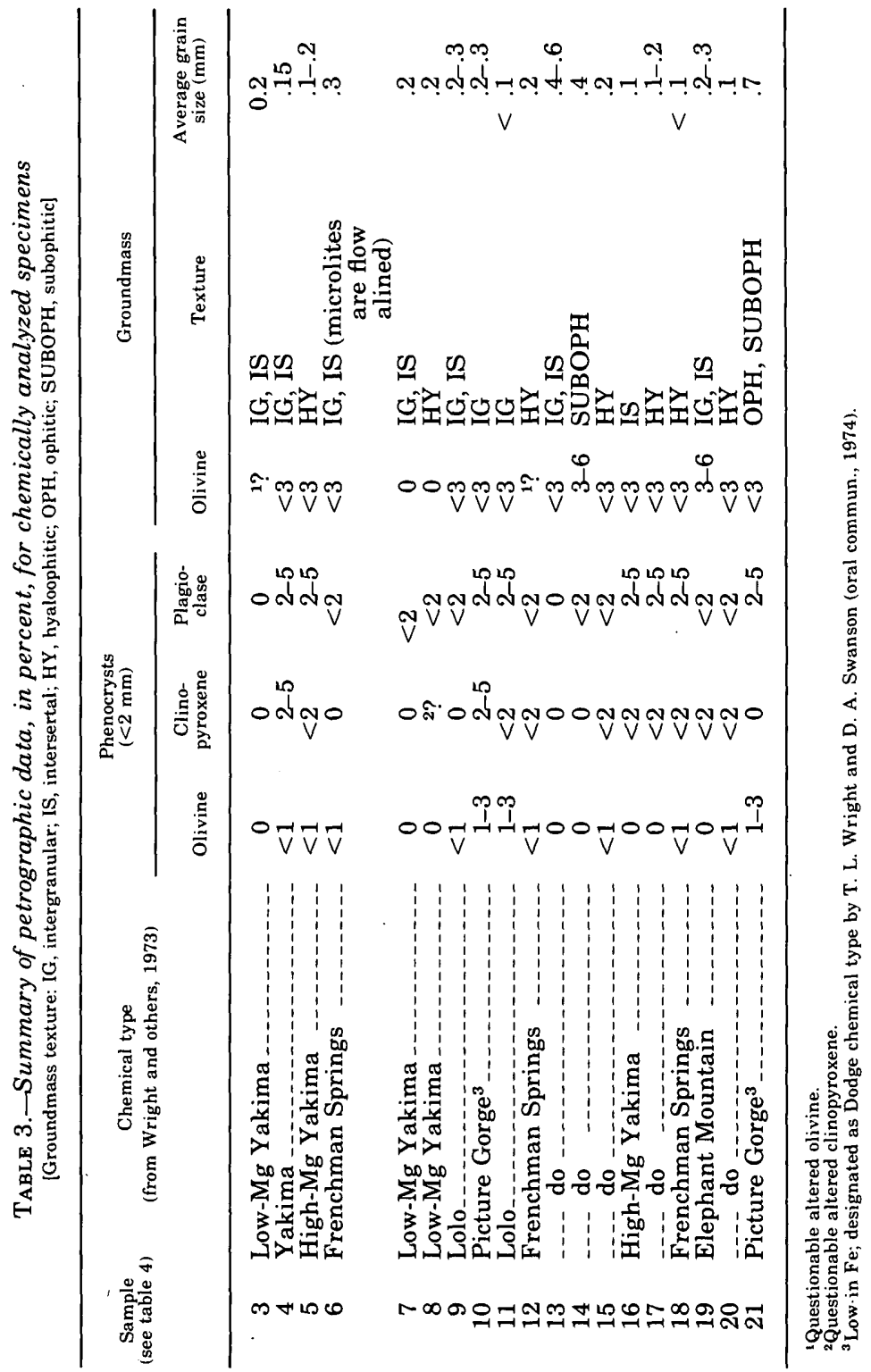


Glass is abundant in most of the specimens. It occurs as dark tachylyte studded by opaque mineral grains in highly glassy samples and as a clear brown residue in the thoroughly crystallized flows (such as samples 14 and 21). Opaque minerals are plentiful as microlites and crystallites in the flows. In the well-crystallized high- $\mathrm{Ti}$ and $-\mathrm{Fe}$ flows, the opaque minerals are especially abundant and commonly occur as long rods and related bizzare forms, presumably of titaniferous magnetite. Microlites and crystallites of all groundmass minerals are oriented randomly, implying crystallization under nearly static conditions after flow had ceased.

The chemical types into which the analyzed flows can be classified cannot be recognized with confidence from these reconnaissance petrographic observations. Some observations are suggestive of a particular chemistry, however. For example, olivine is very rare or absent in flows of low-Mg Yakima chemical type and tends to form larger phenocrysts in flows of Lolo chemical type than in flows of other types. In well-crystallized rocks, abundant rods of titaniferous magnetite indicate a high content of Ti and Fe. Flows of Yakima type composition tend to be glassier than flows of most other compositions, probably because the high $\mathrm{SiO}_{2}$ content slows diffusion rates in the residual melt; however, the rate of cooling and position within a flow must of course be taken into account before applying this criterion.

\section{CHEMISTRY}

A two-fold major stratigraphic division of rocks herein assigned to the Columbia River Basalt Group was recognized by Waters (1961) on the basis of distinctive compositional differences. His older unit, the Picture Gorge Basalt, is mostly restricted to north-central and northeastern Oregon, and his younger unit, the Yakima Basalt, lies mostly to the north, where it covers over two-thirds of the Columbia Plateau. Waters noted that some of the upper flows within the Yakima Basalt in the western part of the plateau constituted a more mafic variant which he designated the "late Yakima petrographic type." Comparing hundreds of analyses of basalts from all over the plateau, many of them from detailed sections, supplemented by field examinations, Wright, Grolier, and Swanson (1973, table 1) expanded Waters' subdivision and proposed an informal four-way stratigraphic breakdown, from oldest to youngest as follows: (1) Picture Gorge Basalt and lower basalt of Bond (1963); (2) lower Yakima basalt (generally synonymous with Waters' Yakima Basalt); (3) middle Yakima basalt (approximately Waters' mafic variant and the Lolo Creek flow of Bond (1963)); and (4) upper Yakima basalt. Each of these stratigraphic units, except the upper Yakima Basalt, is dominated by 1-3 of the 11 chemical types defined by Wright, Grolier, and Swanson (1973). 
Knowledge of the chemistry of a given flow can therefore be used in assigning it to a particular stratigraphic unit, and if chemical data are available for a section of several flows, the stratigraphic assignment is virtually unambiguous.

The Picture Gorge Basalt and the lower basalt of Bond (1963) are characterized by low to intermediate $\mathrm{SiO}_{2}$ (49.0-51.0 percent), relatively high $\mathrm{MgO}$ (4.5-7.1 percent), and generally low $\mathrm{K}_{2} \mathrm{O}(0.6-1.3$ percent). The lower Yakima basalt is dominantly higher in $\mathrm{SiO}_{2}$ (53.5-55.0 percent), relatively lower in $\mathrm{MgO}$ (3.0-5.5 percent); and low to intermediate in $\mathrm{TiO}_{2}$ (1.8-2.3 percent). The middle Yakima basalt is generally low to intermediate in $\mathrm{SiO}_{2}$ (49.0-51.0 percent), high in total iron (14.0 percent; all calculated as $\mathrm{FeO}$ ), high in $\mathrm{TiO}_{2}$ (3.0-3.2 percent), and high in $\mathrm{P}_{2} \mathrm{O}_{5}(0.55-0.75$ percent). The upper Yakima basalt is considerably diversified in composition.

Within the Spokane quadrangle all the exposed basalt flows are apparently a part of either the lower or middle Yakima basalts. Almost all flows within the lower Yakima basalt fall within the high$\mathrm{Mg}$ (average $\mathrm{MgO}, 4.9$ percent), low- $\mathrm{Mg}$ (average $\mathrm{MgO}, 3.4$ percent), or high-Ti (average $\mathrm{TiO}_{2}, 2.35$ percent) Yakima chemical types as designated by Wright, Grolier, and Swanson (1973). All these types are quite similar chemically and petrographically and are intermixed throughout this lower Yakima basalt part of the section. The middle Yakima basalt includes flows that fall within the Lolo, Roza, Frenchman Springs, or Umatilla chemical types of Wright, Grolier, and Swanson (1973). The names applied to these chemically distinct types were derived-and sometimes modified-from named individual flows or flow units that have been mapped over a part of the plateau. All these types also are very similar chemically except for the Umatilla, which is distinctly higher in $\mathrm{SiO}_{2}$ (average, 55.0 percent) and lower in $\mathrm{MgO}$ (average 2.7 percent).

Analyses for major oxides of 21 specimens of basalt from the Spokane quadrangle were done in the analytical laboratories of the U.S. Geological Survey by using the standard rapid-rock analyses method described by Shapiro and Brannock (1962). An additional five analyses of basalt specimens from within the quadrangle are tabulated by Brock and Grolier (1973). All these are listed in table 4, and their location is shown on plate 1 . These analyses have been used to determine the compositional types to be found within the quadrangle, their distribution in several sections, and their inferred stratigraphic relations. Analyses are plotted on a silica variation diagram (fig. 5), where they fall into three major groups. The group with more than 53 percent $\mathrm{SiO}_{2}$ corresponds to the Yakima chemical type of Wright and others (1973, table 2B). The high- $\mathrm{TiO}_{2}$ group includes flows belonging to Lolo and Frenchman Springs chemical types. The low-SiO ${ }_{2}$, low- 
TABLE 4.-Chemical analyses of basalt from the Spokane quadrangle

[Looked for but not detected: Ag, As, Au, B, Be, Bd, Cd, Mo, Pd, Pt, Sb, Te, U, W, Zn. N, not detected; see pl. 1 for location of samples]

\begin{tabular}{|c|c|c|c|c|c|c|c|c|}
\hline & 1 & 2 & 3 & 4 & 5 & 6 & 7 & 8 \\
\hline \multicolumn{9}{|c|}{ Chemical analyses } \\
\hline 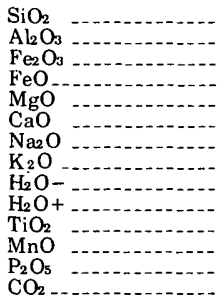 & $\begin{array}{c}53.5 \\
14.6 \\
3.0 \\
8.3 \\
4.1 \\
8.7 \\
2.8 \\
1.2 \\
.68 \\
1.2 \\
1.8 \\
.20 \\
.37 \\
<.05\end{array}$ & $\begin{array}{c}54.1 \\
13.9 \\
1.8 \\
10.9 \\
3.4 \\
6.8 \\
3.2 \\
1.7 \\
.25 \\
1.2 \\
2.3 \\
.22 \\
.42 \\
.08\end{array}$ & $\begin{array}{c}54.2 \\
13.5 \\
2.6 \\
10.1 \\
3.6 \\
6.8 \\
3.0 \\
1.6 \\
.41 \\
1.2 \\
2.1 \\
.18 \\
.40 \\
<.05\end{array}$ & $\begin{array}{r}53.8 \\
13.9 \\
2.5 \\
9.2 \\
4.4 \\
8.1 \\
2.9 \\
1.3 \\
.45 \\
1.0 \\
1.7 \\
.18 \\
.45 \\
<.05\end{array}$ & $\begin{array}{r}53.9 \\
13.3 \\
2.0 \\
9.6 \\
5.4 \\
8.6 \\
2.7 \\
1.2 \\
.34 \\
.99 \\
1.7 \\
.20 \\
.34 \\
<.05\end{array}$ & $\begin{array}{r}49.6 \\
13.3 \\
2.0 \\
13.3 \\
4.4 \\
8.2 \\
2.6 \\
1.3 \\
.25 \\
.84 \\
3.1 \\
.25 \\
.82 \\
<.05\end{array}$ & $\begin{array}{c}56.3 \\
13.2 \\
2.3 \\
9.1 \\
3.5 \\
6.6 \\
3.1 \\
1.9 \\
.20 \\
1.1 \\
1.8 \\
.17 \\
.40 \\
.26\end{array}$ & $\begin{array}{c}55.5 \\
13.4 \\
1.8 \\
10.1 \\
3.4 \\
6.8 \\
3.1 \\
1.8 \\
.21 \\
1.1 \\
2.1 \\
.17 \\
.42 \\
<.05\end{array}$ \\
\hline
\end{tabular}

Semiquantitative spectrographic analyses (parts per million)

\begin{tabular}{|c|c|c|c|c|c|c|c|c|c|}
\hline $\begin{array}{l}\mathrm{Ba} \\
\mathrm{Co} \\
\mathrm{Cr} \\
\mathrm{Cu} \\
\mathrm{La} \\
\mathrm{Nb} \\
\mathrm{Ni} \\
\mathrm{Pb} \\
\mathrm{Sc} \\
\mathrm{Sr} \\
\mathrm{V}-- \\
\mathrm{Y}-- \\
\mathrm{Zr}\end{array}$ & 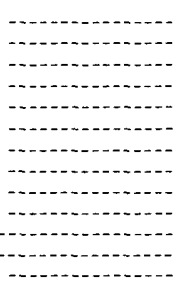 & $\begin{array}{r}700 \\
50 \\
70 \\
50 \\
\mathrm{~N} \\
5 \\
20 \\
\mathrm{~N} \\
70 \\
500 \\
200 \\
30 \\
150\end{array}$ & $\begin{array}{r}700 \\
70 \\
2 \\
15 \\
\mathrm{~N} \\
7 \\
5 \\
\mathrm{~N} \\
70 \\
500 \\
300 \\
50 \\
200\end{array}$ & $\begin{array}{r}700 \\
50 \\
3 \\
20 \\
\mathrm{~N} \\
15 \\
7 \\
15 \\
70 \\
500 \\
300 \\
50 \\
200\end{array}$ & $\begin{array}{r}700 \\
50 \\
50 \\
30 \\
\mathrm{~N} \\
15 \\
15 \\
20 \\
50 \\
500 \\
500 \\
50 \\
150\end{array}$ & $\begin{array}{r}700 \\
50 \\
70 \\
30 \\
\mathrm{~N} \\
10 \\
20 \\
10 \\
70 \\
500 \\
300 \\
50 \\
150\end{array}$ & $\begin{array}{r}700 \\
50 \\
15 \\
20 \\
30 \\
15 \\
20 \\
10 \\
50 \\
500 \\
500 \\
50 \\
150\end{array}$ & $\begin{array}{r}700 \\
50 \\
10 \\
15 \\
\mathrm{~N} \\
10 \\
7 \\
15 \\
50 \\
500 \\
500 \\
50 \\
150\end{array}$ & $\begin{array}{r}700 \\
50 \\
7 \\
15 \\
\mathrm{~N} \\
10 \\
7 \\
10 \\
50 \\
500 \\
500 \\
50 \\
150\end{array}$ \\
\hline
\end{tabular}

'Probably a bad analysis or a sample mix-up, for this flow is the same as sample 22 on the basis of mapping by Swanson and Wright (1973).

1. Columnar basalt just above pillow-palagonite complex, elev 2,000 ft, SE. cor. sec. 4, T. 25 N., R. 42 E., Medical Lake quad, Wash.

2. Hackly fractured basalt, elev $1,750 \mathrm{ft}$, Deep Creek, near center north line, sec. 18, T. 26 N, R. 42 E., Clayton quad, Wash.

3. Hackly fractured basalt, lowest flow above Latah Creek, elev 1,950 ft, SE1/4 sec. 11, T. 23 N., R. 43 N., Spangle quad, Wash.

4. Columnar basalt, second flow above Latah Creek, elev 2,015 ft, south central part sec. 12, T. 23 N., R. 43 E., Spangle quad, Wash.

5. Rudely columnar basalt overlying pillow complex, third flow above Latah Creek, 2,200 ft, on line secs. 12 and 13, T. 23 N.,. R. 43 E., Spangle quad, Wash.

6. Basal columnar basalt, fourth flow above Latah Creek, elev 2,310', NE1/4 sec. 13, T. 23 N., R. 43 E., Spangle quad, Wash.

7. Hackly basalt from knob on Dean St. near Washington St., elev 1,900 ft, Spokane, Wash.

8. Hackly basalt from knob along Perry St. near Third Ave., elev 1,980 ft, Spokane, Wash.

$\mathrm{TiO}_{2}$ group corresponds chemically to the Picture Gorge type, except for a lower iron content. On the basis of this chemistry, most of the flows can be assigned with reasonable assurance to either the lower or middle Yakima basalts. Flows of the low-Fe Picture Gorge chemical type are believed to be an aberrant subtype in the middle Yakima, a point that is discussed later.

Semiquantitative spectrographic analyses for a selected list of minor elements were made of the first 21 samples listed in table 4 . 
TABLE 4.-Chemical analyses of basalt from the Spokane quadrangle-Continued

\begin{tabular}{|c|c|c|c|c|c|c|c|c|c|}
\hline 9 & 10 & 11 & 12 & 13 & 14 & 15 & 16 & 17 & 18 \\
\hline \multicolumn{10}{|c|}{ Chemical analyses-Continued } \\
\hline $\begin{array}{c}49.6 \\
13.6 \\
1.2 \\
13.1 \\
5.4 \\
8.3 \\
2.6 \\
1.2 \\
.32 \\
.88 \\
3.6 \\
.22 \\
.82 \\
<.05\end{array}$ & $\begin{array}{c}50.0 \\
15.5 \\
3.3 \\
7.8 \\
5.8 \\
9.3 \\
3.0 \\
.61 \\
1.1 \\
1.1 \\
1.4 \\
.25 \\
.32 \\
.03\end{array}$ & $\begin{array}{c}49.0 \\
13.9 \\
1.8 \\
12.8 \\
5.2 \\
8.1 \\
2.7 \\
1.2 \\
.20 \\
1.0 \\
3.6 \\
.28 \\
.71 \\
.01\end{array}$ & $\begin{array}{c}49.0 \\
14.1 \\
2.9 \\
11.4 \\
4.1 \\
8.1 \\
2.7 \\
1.2 \\
.81 \\
1.2 \\
3.5 \\
.28 \\
.75 \\
.01\end{array}$ & $\begin{array}{r}50.5 \\
14.2 \\
2.1 \\
11.9 \\
3.9 \\
8.0 \\
2.9 \\
1.2 \\
.27 \\
1.0 \\
3.5 \\
.28 \\
.81 \\
.02\end{array}$ & $\begin{array}{r}49.0 \\
13.9 \\
4.1 \\
10.4 \\
3.9 \\
8.1 \\
2.9 \\
1.2 \\
1.2 \\
1.1 \\
3.6 \\
.28 \\
.69 \\
.01\end{array}$ & $\begin{array}{c}49.5 \\
14.1 \\
2.1 \\
12.2 \\
4.5 \\
8.1 \\
2.8 \\
1.3 \\
.32 \\
.88 \\
3.6 \\
.32 \\
.78 \\
.01\end{array}$ & $\begin{array}{c}53.4 \\
14.1 \\
1.5 \\
10.2 \\
4.5 \\
8.3 \\
2.9 \\
1.3 \\
.34 \\
.76 \\
1.9 \\
.22 \\
.46 \\
<.05\end{array}$ & $\begin{array}{c}53.5 \\
14.1 \\
.60 \\
11.0 \\
4.5 \\
8.1 \\
2.8 \\
1.4 \\
.31 \\
.89 \\
1.9 \\
.23 \\
.43 \\
<.05\end{array}$ & $\begin{array}{c}49.5 \\
13.0 \\
4.5 \\
9.8 \\
4.1 \\
8.3 \\
2.5 \\
1.3 \\
.96 \\
.94 \\
3.6 \\
.24 \\
.81 \\
<.05\end{array}$ \\
\hline
\end{tabular}

Semiquantitative spectrographic analyses (parts per million)-Continued

\begin{tabular}{|c|c|c|c|c|c|c|c|c|c|}
\hline $\begin{array}{r}500 \\
50 \\
15 \\
30 \\
\mathrm{~N} \\
10 \\
\mathrm{~N} \\
10 \\
70 \\
500 \\
300 \\
50 \\
150\end{array}$ & $\begin{array}{r}500 \\
50 \\
200 \\
100 \\
\mathrm{~N} \\
10 \\
50 \\
\mathrm{~N} \\
70 \\
500 \\
300 \\
20 \\
100\end{array}$ & $\begin{array}{r}700 \\
50 \\
20 \\
15 \\
30 \\
15 \\
20 \\
\mathrm{~N} \\
50 \\
500 \\
500 \\
50 \\
100\end{array}$ & $\begin{array}{r}700 \\
50 \\
20 \\
15 \\
30 \\
15 \\
20 \\
\mathrm{~N} \\
50 \\
500 \\
500 \\
50 \\
100\end{array}$ & $\begin{array}{r}700 \\
50 \\
15 \\
20 \\
30 \\
15 \\
15 \\
\mathrm{~N} \\
50 \\
500 \\
500 \\
50 \\
100\end{array}$ & $\begin{array}{r}700 \\
50 \\
15 \\
20 \\
30 \\
15 \\
15 \\
\mathrm{~N} \\
50 \\
500 \\
500 \\
50 \\
100\end{array}$ & $\begin{array}{r}700 \\
50 \\
20 \\
20 \\
\mathrm{~N} \\
15 \\
20 \\
\mathrm{~N} \\
50 \\
500 \\
500 \\
50 \\
100\end{array}$ & $\begin{array}{r}500 \\
50 \\
30 \\
30 \\
\mathrm{~N} \\
10 \\
15 \\
7 \\
30 \\
500 \\
200 \\
30 \\
100\end{array}$ & $\begin{array}{r}500 \\
50 \\
30 \\
30 \\
\mathrm{~N} \\
15 \\
15 \\
7 \\
30 \\
500 \\
200 \\
30 \\
100\end{array}$ & $\begin{array}{r}500 \\
50 \\
15 \\
20 \\
30 \\
20 \\
20 \\
7 \\
30 \\
500 \\
300 \\
50 \\
150\end{array}$ \\
\hline
\end{tabular}

9. Columnar basalt, elev $2,280 \mathrm{ft}$, NW/4 sec. 27 , T. 25 N., R. 42 E., Spokane quad, Wash.

10. Columnar basalt just above base of flow, elev $2,340 \mathrm{ft}$, along Highway $95 \mathrm{~A}$, center sec. 6, T. 45 N., R. 1 W, St. Maries quad, Idaho.

11. Basalt from basal columns, next flow above sample 10, along Highway $95 \mathrm{~A}, \mathrm{SE} 1 / 4$ sec. $6, \mathrm{~T} .45 \mathrm{~N}$., R. 1 W, St. Maries quad, Idaho.

12. Columnar basalt, along Highway $95 \mathrm{~A}$, elev $2,620^{\prime}$, NE. cor. sec. 7, T. 45 N., R. 1 W, St. Marjes quad, Idaho.

13. Columnar basalt, along Highway 95A, elev 2,700', near center sec. 8, T. 45 N., R. 1 W. St. Joe quad, Idaho.

14. Hackly basalt from borrow pit along Highway $95 \mathrm{~A}$, elev $2,760 \mathrm{ft}$, SW $1 / 4 \mathrm{sec}$. 8 , T. 45 N., R. 1 W., St. Joe quad, Idaho.

15. Hackly basalt from roadcut along Highway $95 \mathrm{~A}$, just below top surface, elev $3,000 \mathrm{ft}, \mathrm{NE} 1 / \mathrm{s} \mathrm{sec} .18, \mathrm{~T}$. $45 \mathrm{~N}$., R. 1 W., Emida quad, Idaho.

16. Columnar basalt at O'Gara Bay, elev 2,140 ft, line between secs. 20 and 21 , T. 47 N., R. 3 W., St. Maries quad, Idaho.

17. Basalt from basal columns from small rock quarry, elev $2,210 \mathrm{ft}$, SE⿺𠃊1/4 sec. 7, T. 47 N., R. 3 W., Plummer quad., Idaho.

18. Columnar basalt from along Highway $95 \mathrm{~A}$, elev $2,420 \mathrm{ft}, \mathrm{SW} 1 / 4 \mathrm{sec} .6, \mathrm{~T} .47 \mathrm{~N} ., \mathrm{R} .3 \mathrm{~W}$., Plummer quad, Idaho.

Results are reported to the nearest number in the series $1,0.7,0.5$, $0.3,0.2,0.15$, and 0.1 , etc., which represent approximate midpoints of group data on a geometric scale. The assigned group for semiquantitative results includes the quantitative value about 30 percent of the time. These analyses show that the samples contain similar contents of all detectable elements except chromium, copper, and nickel, which are noticeably higher in the two low-Fe Picture Gorge analyses.

Samples 1 through 9 are all from the general Spokane area. Samples 1, 2, 7, and 8 are from the so-called "valley" flows of Pardee and Bryan (1926). They are all of the low-Mg Yakima chemical type and 
TABLE 4.-Chemical analyses of basalt from the Spokane quadrangle-Continued

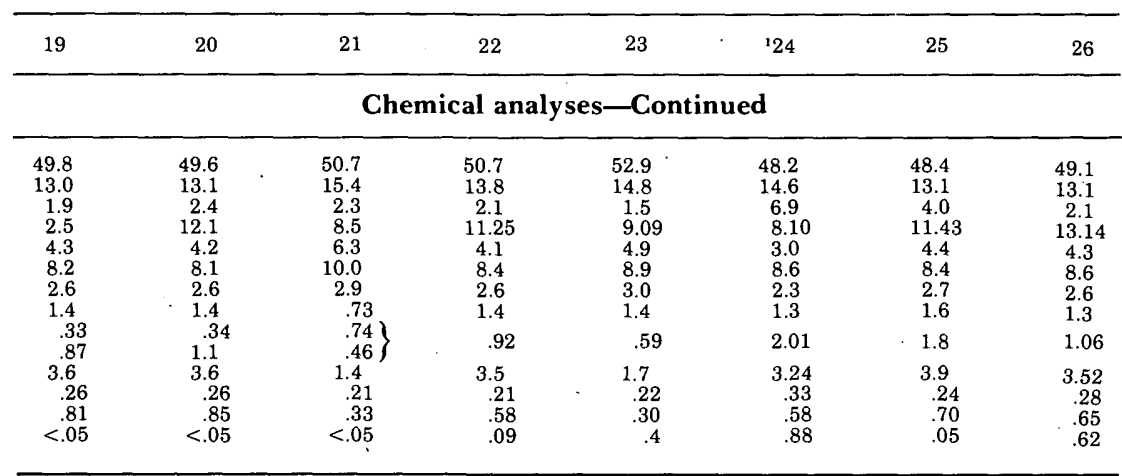

Semiquantitative spectrographic analyses (parts per million)-Continued

\begin{tabular}{|c|c|c|c|c|c|c|c|}
\hline 500 & 500 & 300 & --- & $\ldots$ & --- & $-\cdots$ & $\ldots$ \\
\hline 50 & 50 & 50 & $\ldots$ & $\ldots$ & $\cdots-$ & $\ldots$ & $\ldots$ \\
\hline 10 & 10 & 200 & --- & $\ldots$ & $\cdots$ & - - & $\ldots$ \\
\hline 20 & 20 & 100 & $\ldots$ & $\ldots$ & $\ldots$ & $\ldots$ & $\ldots$ \\
\hline 30 & 30 & $\mathrm{~N}$ & $\ldots$ &.- & $\ldots$ & -.. & $\ldots$ \\
\hline 20 & 15 & 7 & $\ldots$ & $\ldots$ & $\cdots-$ & +- & --- \\
\hline 20 & 20 & 50 & -... & $\ldots$ & $-\cdots$ & --- & $\cdots$ \\
\hline 7 & 7 & $\mathrm{~N}$ & 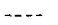 & $\cdots$ & $\cdots$ & $-\cdots$ & --- \\
\hline 30 & 30 & 70 & $\ldots$ & $\cdots$ & $\cdots$ & +- & $-\cdots$ \\
\hline 500 & 500 & 500 & $-\ldots$ & ---- & $-\cdots$ & $\cdots$ & $\ldots$ \\
\hline 300 & 300 & 300 & $\ldots$ & $\ldots$ & $\cdots$ & $--\cdot$ & $-\cdots$ \\
\hline 50 & 50 & 30 & $\ldots$ & $\ldots$ & $\cdots$ & --- & $\therefore$ \\
\hline 150 & 150 & 100 & $\ldots$ & $-\cdots$ & $\cdots$ & $\cdots$ & $\cdots$ \\
\hline
\end{tabular}

19. Columnar basalt from along Highway $95 \mathrm{~A}$, elev $2,650 \mathrm{ft}, \mathrm{NW} 1 / 4$ sec. $8, \mathrm{~T} .47 \mathrm{~N}$., R. 3 W., Plummer quad, Idaho.

20. Hackly basalt from small quarry along Highway 3 , elev $2,780 \mathrm{ft}$, near center sec. 24 , T. 47 N., R. 3 W., St. Maries quad, Idaho.

21. Columnar basalt from just above St. Maries River, elev $2,140 \mathrm{ft}$, south line of sec. 4, T. 46 N., R. 2 W., St. Maries quad, Idaho.

22. Roadcut west of Kenova and west of Pine Creek, elev 2,030 ft, NW1/4 sec. 29, T. 20 N., R. 42 E., Pine City quad, Wash. (70-B-53 in Brock and Grolier, 1973).

23. From scarp above bench on north side of Rock Creek, elev $2,020 \mathrm{ft}, \mathrm{NW} 1 / 4 \mathrm{SW} 1 / 4$ sec. 12, T. 20 N., R. 41 E., Pine City quad, Wash. (70-B-54 in Brock and Grolier, 1973).

24. Just above and west of sample 23 . elev $2,090 \mathrm{ft}, \mathrm{NW} 1 / 4 \mathrm{SW} 1 / 4$ sec. $12, \mathrm{~T} .20 \mathrm{~N} ., \mathrm{R}, 41$ E., Pine City quad, Wash. (70-B-55 in Brock and Grolier, 1973).

25. Just above sample 24 , elev $2,150 \mathrm{ft}, \mathrm{NW} 1 / 4 \mathrm{SW} 1 / 4$ sec. 12, T. 20 N., R. 41 E., Pine City quad, Wash. (70-B-56 in Brock and Grolier, 1973).

26. Cut above Highway $23,2.5$ mi north of Rock Creek, elev $1,850 \mathrm{ft}, \mathrm{NW} 1 \frac{1}{4} \mathrm{SW} 1 / 4$ sec. $29, \mathrm{~T}$. $19 \mathrm{~N}$., R. $40 \mathrm{E}$., Texas Lake quad, Wash (70-B-243 in Brock and Grolier, 1973).

hence probably belong to the lower Yakima basalt. Sample 9 is from one of the "rim rock" flows just west of Spokane; it is of high- $\mathrm{TiO}_{2}$ Lolo type and most likely belongs to the middle Yakima basalt. Samples 3 , 4,5 , and 6 are from a section of flows above Latah Creek about $12 \mathrm{mi}$ $(20 \mathrm{~km})$ south of Spokane. Samples 3, 4, and 5 from the lower flows are all of the Yakima chemical type, whereas sample 6, which caps the other three flows and is the highest flow exposed at this locality, is of the Frenchman Springs chemical type. The compositional data corroborate both the field mapping and the well logs in showing that the "valley" flows are a part of the normal sequence that lies under the "rim rock" flows rather than being later intracanyon flows. The capping flows in the general Spokane area are of compositions consistent with an assignment to the middle Yakima basalt. 
Samples 16 through 20 are from a section of intermittently exposed flows between Coeur d'Alene Lake and the top of the basalt plateau near Harrison, Idaho. Here the two lower flows are of the high-Mg. Yakima chemical type. The upper three flows closely resemble the Frenchman Springs chemical type of Wright, Grolier, and Swanson (1973), except for high $\mathrm{TiO}_{2}$, and the Elephant Mountain chemical type, except for low Fe. Wright, Grolier, and Swanson (1973, p. 384) noted that some flows of otherwise equivalent composition have a higher $\mathrm{TiO}_{2}$ content in the eastern part of the plateau than in the rest of the plateau. Thus the three flows can reasonably be considered as Frenchman Springs chemical type having a high- $\mathrm{TiO}_{2}$ composition, and their relative position most likely places them within the middle Yakima basalt.

Samples 10 through 15 are from a section of flows intermittently exposed along Highway 95A, 5-8 mi $(8-13 \mathrm{~km})$ southeast of St. Maries, Idaho. Sample 21 is from the flow that apparently lies directly under this section but was collected from an exposure along the St. Maries River about $4 \mathrm{mi}(6.5 \mathrm{~km})$ to the west. Both samples 10 and 21 are of Picture Gorge chemical type but with a low iron content. The overlying flows, samples 11 through 15 , probably all belong to the middle Yakima basalt on the basis of chemistry; 11 is of high$\mathrm{TiO}_{2}$ Lolo chemical type, and all the others are of high-TiO Frenchman Springs type. This stratigraphic sequence is unusual for several reasons. First, the middle Yakima basalt apparently conformably caps the Picture Gorge chemical type without any intervening lower Yakima basalt. This is even more unusual because a normal stratigraphic relation, with middle Yakima flows overlying lower Yakima flows, occurs in the Harrison section only 12-15 mi $(20-24 \mathrm{~km})$ to the northwest. The nearest Picture Gorge Basalt is more than $130 \mathrm{mi}(210 \mathrm{~km})$ southwest of the area, and only a few flows of Picture Gorge chemical type occur in the lower basalt of Bond (1963) in the Clearwater Embayment, about $60 \mathrm{mi}(100 \mathrm{~km})$ to the south. A probable explanation has been proposed by D. A. Swanson and T. L. Wright (oral commun., 1973), who found at least two flows of a very similar composition (Brock and Grolier, 1973, sample DSTW 71-57) near Pomeroy, Wash., $75 \mathrm{mi}(120 \mathrm{~km})$ to the southwest. The flows are interlayered there with several flows having Frenchman Springs chemistry and one having Yakima chemistry. Swanson and Wright suggest that flows of this composition may be a new and different variety. Because of the relative position of the flows at St. Maries, these flows of the low-iron Picture Gorge chemical type are probably at or above the base of the middle Yakima basalt of Wright, Grolier, and Swanson (1973).

Five of the analyses listed by Brock and Grolier (1973) are of sam- 

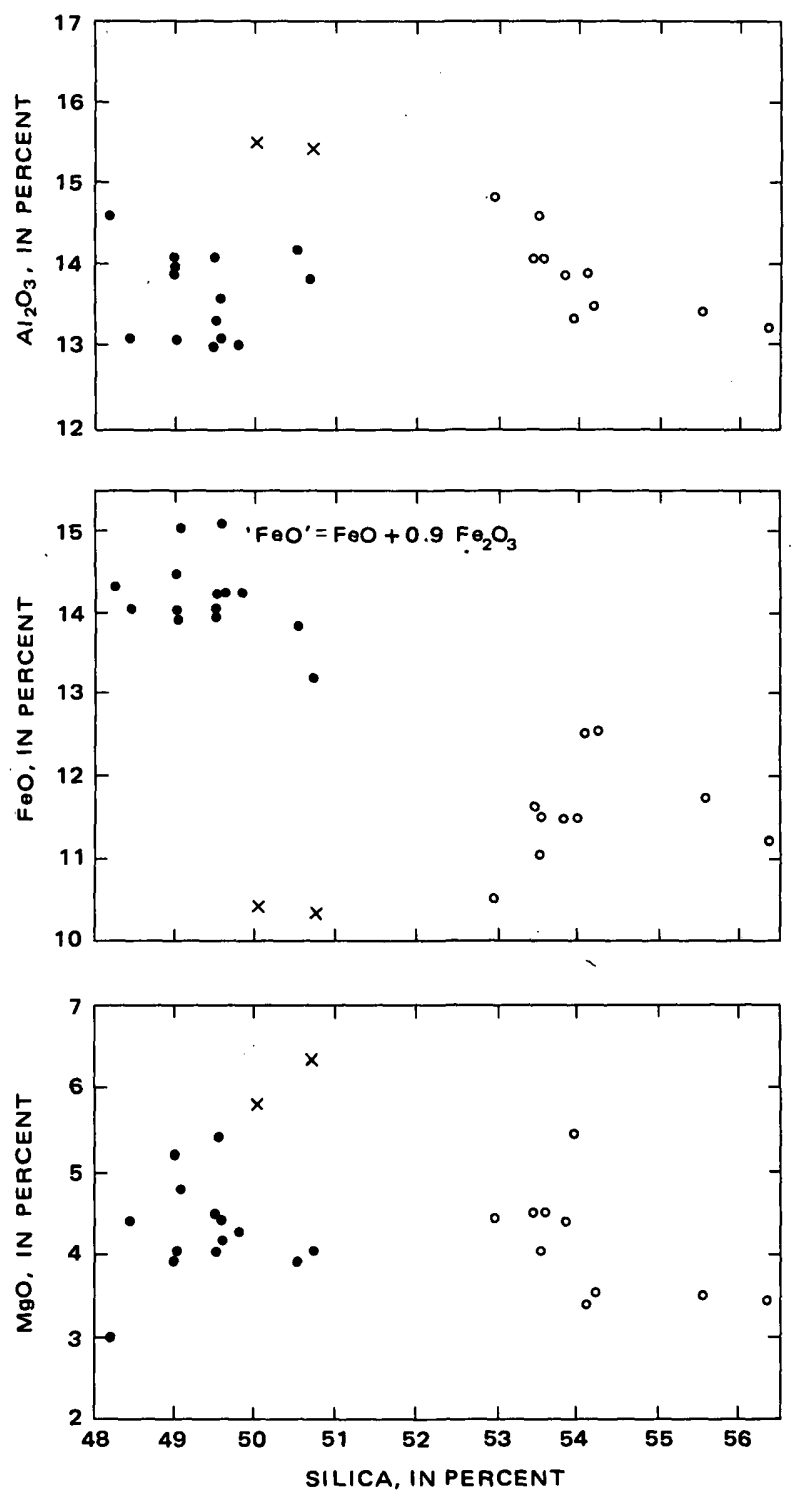

EXPLANATION

- Lolo, Frenchman Springs, and possible Elephant Mountain chemical types

- Yakima type

$\times$ Low-iron Picture Gorge type

Figure 5.-Silica variation diagram of basalts from the $\forall$ Spokane quadrangle. 
CHEMISTRY
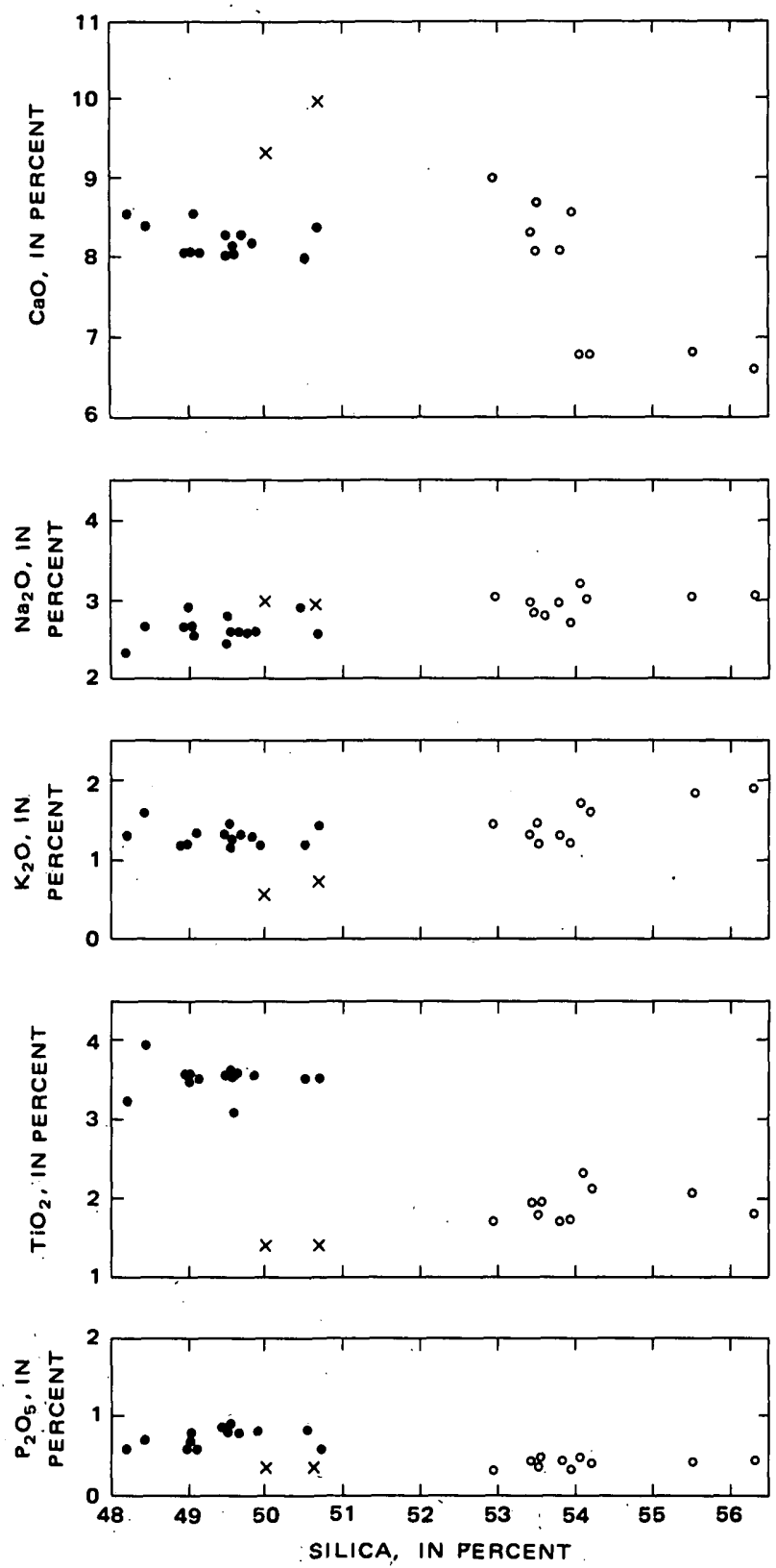

Figure 5.-Continued.

ples collected from the southwest corner of the Spokane quadrangle. These are shown in table 4 as samples 22 through 26 . Sample 22 is from the Roza Member on the basis of mapping by Swanson and Wright (1973). Samples 23 through 25 are from a nearby locality, just 
north of Rock Lake; 23 is a high-Mg Yakima type; 24 overlies 23 and is from the Roza Member but is a bad analysis, and 25, which overlies 24, has Elephant Mountain chemistry. These samples are from one of the deeper scabland channels where nearly 300 feet $(90 \mathrm{~m})$ of lower Yakima basalt and slightly more than 100 feet of middle Yakima basalt are exposed. Sample 26 is also of Elephant Mountain chemistry and may be the same flow as 25 although from 13 miles to the southeast. Mapping by D. A. Swanson and T. L. Wright suggests that the flows of Elephant Mountain chemistry in this area are within the middle Yakima basalt.

\section{STRATIGRAPHIC CONCLUSIONS BASED ON CHEMISTRY}

A fair appreciation of the distribution and relative importance of the stratigraphic units of basalt within the Spokane quadrangle has been gained from the stratigraphic implications of these analyses. Discounting the possibility that the lower flows in the St. Joe-St. Maries drainages are stratigraphically a part of the Picture Gorge Basalt, none of this unit is exposed in the quadrangle. Any drainage that has cut more than several hundred feet into the basalt probably will have exposed one or more flows of the lower Yakima basalt. This unit must make up by far the greatest volume of basalt underlying the Spokane quadrangle, even though its areal exposure is not large.

A sedimentary interlayer appears to provide a break between the lower Yakima basalt and the middle Yakima basalt in part of the area. It is present in the vicinity of Spokane and also in the analyzed sections near Harrison and southeast of St. Maries and apparently is widespread.

Flows of the middle Yakima basalt are the most widely distributed and best exposed flows in the quadrangle. In the vicinity of Spokane and to the southwest, the outcropping flows are of this unit; they most likely consist of two to four flows with a combined thickness of 200 to almost $400 \mathrm{ft}$. The sections near Harrison and St. Maries indicate that the middle Yakima basalt has accumulated to a thickness of $400-500 \mathrm{ft}(120-155 \mathrm{~m})$ along the east margin of the plateau in the southern part of the quadrangle.

Earlier investigators (Dort, 1967; Bishop, 1969) of the basalt flows in the valleys of the St. Joe and St. Maries Rivers considered that at least some of the upper flows within these valleys were of local origin and distinctly younger than the underlying flows of the Columbia River Basalt Group. Several of the upper flows in the analyzed section southeast of St. Maries would be included within this group of younger flows, yet their composition and stratigraphic relations show them to be probably a part of the middle Yakima basalt. In addition, so-called "feeder dikes," identified by Bishop (1969), appear to be apophyses of flows that invaded the then-unconsolidated sediments 
over which the basalt had flooded. No basalt dikes that crosscut the underlying Belt supergroup have been described or observed in these drainages. A steeper westerly slope for the top flows near the mouth of the St. Joe valley was suggested to show that these had flowed westward and were of local origin. However, if the tops of flows in landslide blocks near the mouth of the valley are disregarded, the upper surface of the basalt remnants agrees quite well with an expected slope to the west due to a general subsidence in that direction. Thus it is believed that all the basalts in the St. Joe and St. Maries drainages are a part of the Columbia River Basalt Group and that they most likely flowed eastward and up the river valleys from fissures along the east edge of the plateau, as inferred from flow directions in pillow-palagonite complexes (pl. 1).

The principal groups of basalt are thought to have come from separate magmas principally because of the lack of transition compositions that would be produced by differentiation of a single magma (Waters, 1961; Snavely and others, 1973; Wright and others, 1973). Each parent magma must have been generated at a unique level below the plateau, and some magmas must have overlapped one another in time or been regenerated repeatedly because flows of different major chemical types are interlayered at least locally, particularly near contacts (Wright and others, 1973). The presence of the low-iron Picture Gorge type apparently below or interlayered with middle Yakima flows in the section southeast of St. Maries is an example of such repetition.

\section{LATAH FORMATION}

The name Latah Formation was applied by Pardee and Bryan - (1926) to the lacustrine and fluviatile rocks of middle Tertiary age in the Spokane area. They described the unit as having been deposited on an irregular surface underlain by granitic and schistose rocks, upon which it accumulated continuously until reaching a maximum thickness of about $1,500 \mathrm{ft}(460 \mathrm{~m})$. It was finally capped by several flows of the Columbia River Basalt Group. They considered the unit only local in distribution, restricted to within $10-20 \mathrm{mi}(16-32 \mathrm{~km})$ of Spokane and extending eastward to the vicinity of Coeur d'Alene, Idaho. Kirkham and Johnson (1929) proposed a geographic expansion of the term to include all the sedimentary deposits they found interlayered or immediately underneath the basalt flows along the east margin of the plateau in Idaho. They enumerated 40 localities scattered over a distance of almost $150 \mathrm{mi}(240 \mathrm{~km})$ southeast of Spokane where sedimentary strata were assigned by them to the Latah. They proposed that a similar occurrence at the head of Grand Coulee, Wash., about $80 \mathrm{mi}(130 \mathrm{~km})$ west-northwest of Spokane, also be included in the Latah. In his study of the clay deposits of Spokane 
County, Hosterman (1969) included in the Latah some stratified sedimentary deposits that apparently cap the uppermost flows in places. These upper deposits are very similar to neighboring interlayered strata and, like the basalt, are also covered by loess of the Pleistocene Palouse Formation.

In the Spokane quadrangle, similar lacustrine and fluviatile rocks were found interlayered with the basalt flows throughout the marginal area of the plateau. In the northwest corner of the quadrangle, they are prominent in the landslide material on either side of the valley of Chamokane Creek and at places along the south wall of Spokane valley. These sedimentary rocks occur at numerous other localities along the north edge of the map area eastward to the margin of the basalt along the east side of Rathdrum Prairie. From there southward along the east margin of the plateau, scattered occurrences are known from manmade outcrops, landslide blocks, anc ${ }^{i}$ water-well logs. They are particularly plentiful around Coeur d'Alenı Lake and along the lower parts of the St. Joe and St. Maries valleys.

Most of these sedimentary layers range from claystone to finegrained sandstone, in which very finely laminated siltstone is predominant. Coarser grained sandstone and conglomerate are less common and generally occur in basal layers or as fluviatile deposits. The fresh rock ranges in color from various shades of gray to almost white, tan, and rust. Except for some of their capping rock that is cemented with iron oxides, all these lithologies are poorly indurated and can be chipped away easily with a pick. Their mineralogical makeup-quartz, micas, feldspar, clay minerals, rock fragments, and minor heavy minerals-reflects nearby sources in the basement rock. Thin lignitic seams have been noted at several localities, and volcanic material, particularly glass shards, has been noted in some layers. Hosterman (1969) believed that montmorillonite present in one deposit might have resulted from the alteration of volcanic ash.

Many of the finer grained strata are filled with leaf impressions and those of other plant debris. A large varied flora from the Latah has been studied by several investigators (Knowlton, 1926; Berry, 1929; Brown, 1937; Chaney and Axelrod, 1959), and the general concensus is that it is of middle to late Miocene age. This flora includes many deciduous trees that are closely akin to those found in modern forests of the mid-Atlantic states. Diatom remains are a common constituent at places in these deposits, and Hosterman (1969) noted the presence of sponge spicules at several localities in the Spokane area.

Because of its poorly indurated state, the Latah rarely forms outcrops. It is usually concealed under subdued soil-covered slopes or is hidden under the rubble of the overlying basaltic rocks in areas of 
steeper terrain. Its presence usually is apparent only in manmade excavations, landslide areas, and clay pits; however, logs of wells show that it is widespread in the subsurface. Most outcrops expose only about $5 \mathrm{ft}(1.5 \mathrm{~m})$ to slightly more than $20 \mathrm{ft}(6 \mathrm{~m})$ of the Latah, and the thickest sections, exposed in several clay pits, are less than $100 \mathrm{ft}(30 \mathrm{~m})$ thick. Most sections of Latah sedimentary rocks cut by the many wells in the marginal part of the plateau do not exceed 100 $\mathrm{ft}(30 \mathrm{~m})$ in thickness, and many are only a few feet thick. In a few of the deep wells, several hundreds of feet (100 m or more) of strata have been intersected between the lowest basalt flow and the underlying crystalline bedrock. By far the thickest such intercept was in the Latah-Texas well drilled along Latah Creek at the west edge of Spokane (Pardee and Bryan, 1926), where stratified rocks over $800 \mathrm{ft}$ $(244 \mathrm{~m})$ thick was intersected. It was not known whether these $k$ sedimentary rocks belong to the Latah Formation or to a lower s: sequence.

Pardee and Bryan (1926) believed that the Latah Formation consisted of a continuous section of lacustrine and fluviatile strata about $1,500 \mathrm{ft}(460 \mathrm{~m})$ thick. They reasoned that a west-trending ridge of pre-Tertiary rocks just south of Spokane, parts of which still protrude above the basalt, was a barrier to the earlier basalt flows whose source was considered to be to the south and west. North of this barrier the Latah Formation accumulated uninterruptedly until the final two to four capping "rim rock" flows overtopped the barrier. They considered that all the basalt exposed below the "rim rock" flows in the Spokane area either were a part of a distinctly later "valley" sequence or were sills or dikes. This sequence was not extruded until erosion had cut down through the "rim rock" flows and Latah rocks to form a valley several hundred feet below its present level. The valley flows then filled the dissected terrain almost to the level of the original plateau surface. The "rim rock" flows and "valley" sequence also were noted by Pardee and Bryan to have different petrographic characteristics.

The geologic mapping of the Spokane quadrangle has shown that the basalt flows and sedimentary deposits are interlayered in the Spokane area just as in all other places in the peripheral parts of the plateau. The "valley" flows have been found to be part of the lower Yakima basalt and are older than the "rim rock" flows. The Latah Formation also was found at several different horizons that were separated by the "valley" flows or what had been considered as sills by Pardee and Bryan.

Subsurface data confirm the interlayered relations mapped on the surface. The logs of numerous water wells west and north of Spokane show interbedded basalt and sedimentary strata. In addition, inter- 
vals of basalt or sedimentary rock of comparable thickness and at similar elevations are duplicated in most adjacent wells (fig. 6). The well logs also show that the generally regular and continuous interlayered relations vary locally and that some sedimentary layers pinch and swell and wedge out in short distances. Discomformable relations between a sedimentary layer and the overlying flow at scattered localities and at different elevations indicate that local erosion during the period of sedimentary accumulation was common. This factor plus the wedging out of flows apparently account for some of the irregularities in the thickness of the sedimentary layers indicated by subsurface data.

It is suggested here that the Latah Formation be restricted geographically to those sedimentary rocks associated with the Columbia River Basalt Group within the Spokane River drainage, including that above Cour d'Alene Lake in the lower part of the St. Joe and Coeur d'Alene River drainages. This would exclude widely scattered localities like those at Grand Coulee to the northwest and many others in the Clearwater River drainage, $150 \mathrm{mi}(240 \mathrm{~km})$ to the southeast, that were included by Kirkham and Johnson (1929). Gray and Kittleman (1967) also believed that such an extension of the Latah was not warranted. They reasoned that in such a large region several local basins of sedimentation probably existed, and although commonly interlayered with basalt flows, the sedimentary rocks in each were not necessarily part of a single widespread formation. The sedimentary layers in the Spokane area are intercalated with the Yakima Basalt, whereas in the Clearwater River embayment some of the sediments are known to be interlayered with the older, lower basalt of Bond (1963). Thus unless the Latah is geographically restricted, the formation would be interlayered with two or more different formations. Although none of the individual sedimentary interlayers has been systematically traced within the Spokane quadrangle, some may be fairly widespread. Field relations and well intercepts indicate that several interlayers may be continuous over large parts of the basin. Others are apparently more limited and pinch ut in short distances.

\section{LANDSLIDES}

Landslides involving the Columbia River Basalt Group and interlayered lacustrine and fluviatile deposits were noted in some of the earliest investigations of the plateau country (Russell, 1893; Lindgren, 1901) and are common in the periphery of the plateau in the Spokane quadrangle (pl. 1). These all occur adjacent to the steep valley walls of major stream courses and around the so-called "prairies and bluffs" north and northeast of Spokane. They range in 
size from areas miles long and a mile or more across to individual large blocks of basalt, $\pm 25 \mathrm{ft}(8 \mathrm{~m})$ across. They are prevalent at three scattered localities within the quadrangle: (1) the northwest corner of the map area, (2) the vicinity of Spokane, and (3) near St. Maries, Idaho, at the confluence of the St. Joe and St. Maries Rivers.

The greatest concentration of landslides is in the northwest corner of the Spokane quadrangle. There large slides occur on both sides of Walkers Prairie and along the steep south wall of the Spokane River valley. The largest slide area, bordering the northwest margin of Walkers Prairie and north of Little Chamokane Creek, is continuous for over $12 \mathrm{mi}(20 \mathrm{~km})$ and is as much as 1 mile $(1.5 \mathrm{~km})$ across at several places. Each of the other areas covers $1 \mathrm{mi}^{2}\left(2.5 \mathrm{~km}^{2}\right)$ or more, and one along the south edge of the Spokane valley is continuous for over $4 \mathrm{mi}(6.5 \mathrm{~km})$. Broken basalt along ill-formed low ridges is about the only rock exposed naturally in the slides. The intermixed sedimentary rock is exposed largely in roadcuts. Some slides are veneered with glacial debris, which further obscures their internal composition.

Five Mile Prairie, Orchard Bluff, Green Bluff, Pleasant Prairie, and Orchard Prairie north and northeast of Spokane are all basaltcapped plateau remnants that stand from 300 to $400 \mathrm{ft}(90-120 \mathrm{~m})$ above the surrounding lowlands. Landslide areas are evident around the margins of all of them and have almost completely ringed Orchard Bluff. In this same general vicinity, landslide areas also have been noted along the Little Spokane and Spokane Rivers and Latah Creek. In all these landslides, about the only natural exposures are of broken basalt, and the intermixed sedimentary rock is seen only in manmade excavations. However, logs of several wells (fig. 6) show that most of the rock underlying those plateau remnants belongs to the Latah Formation, with only a flow or two locally interlayered with the sediments.

Large areas of landslide material bound both valley walls of the St. Maries River where it joins the St. Joe River. Other landslide blocks are scattered along the margins of the St. Joe River valley farther west to where it flows into Coeur d'Alene Lake. At least fojur interbeds of relatively weak sedimentary rocks are known to be interlayered with the basalt in this area. Here also some of the slide blocks have broken away from and moved upon the Precambrian Belt Supergroup that formed the ancient valley walls. The landslide blocks slid into a valley that apparently was several hundred feet (about $100 \mathrm{~m}$ ) deeper than at present. The toes have been buried under the alluvial fill that has been accumulating since Coeur d'Alene Lake was formed behind a dam of glacial debris in late Pleistocene time. 
in

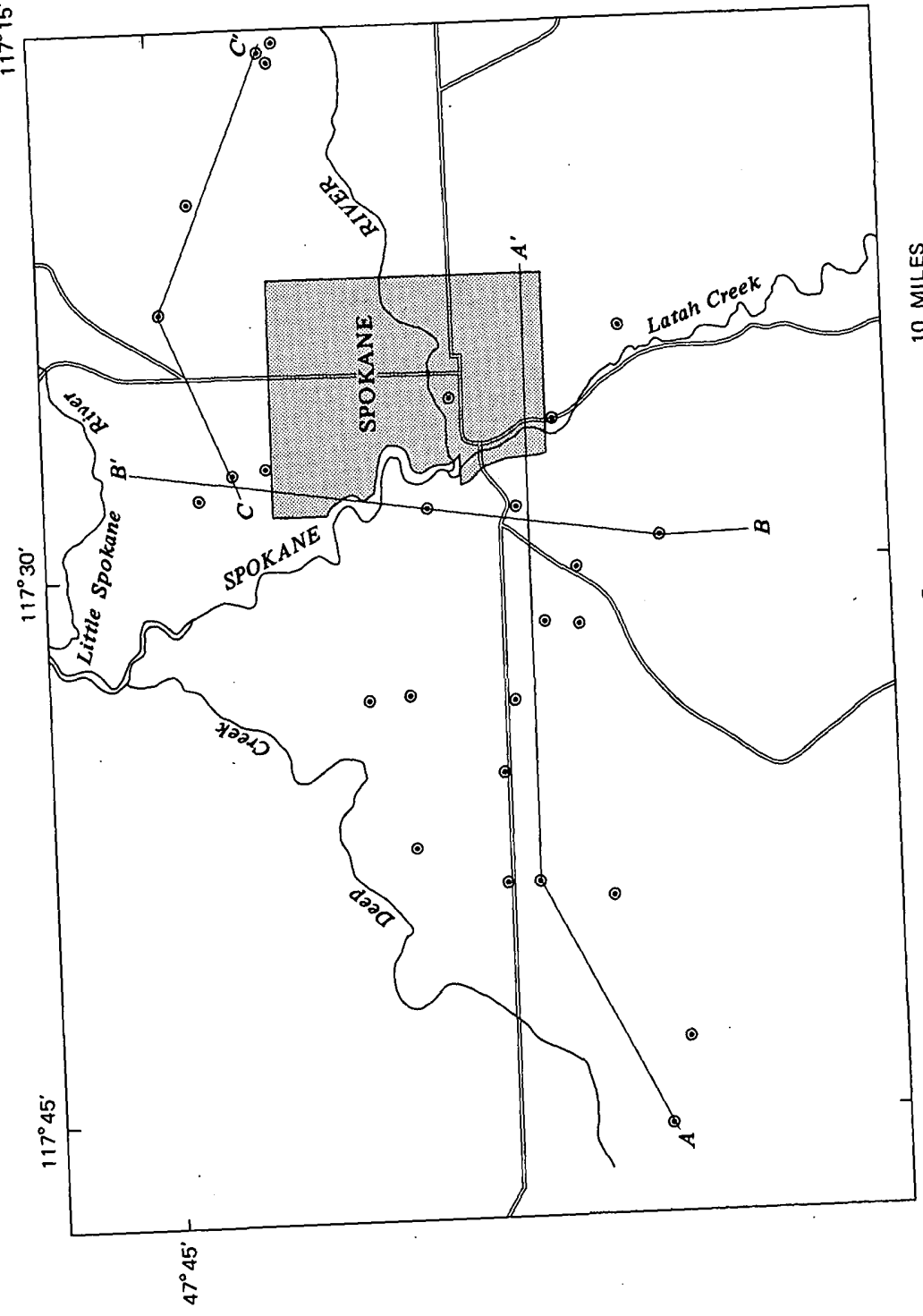

$\rightarrow$

4

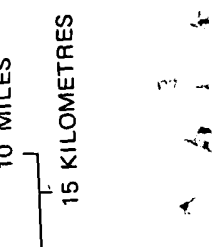

-으

$n-$

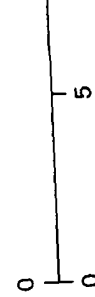




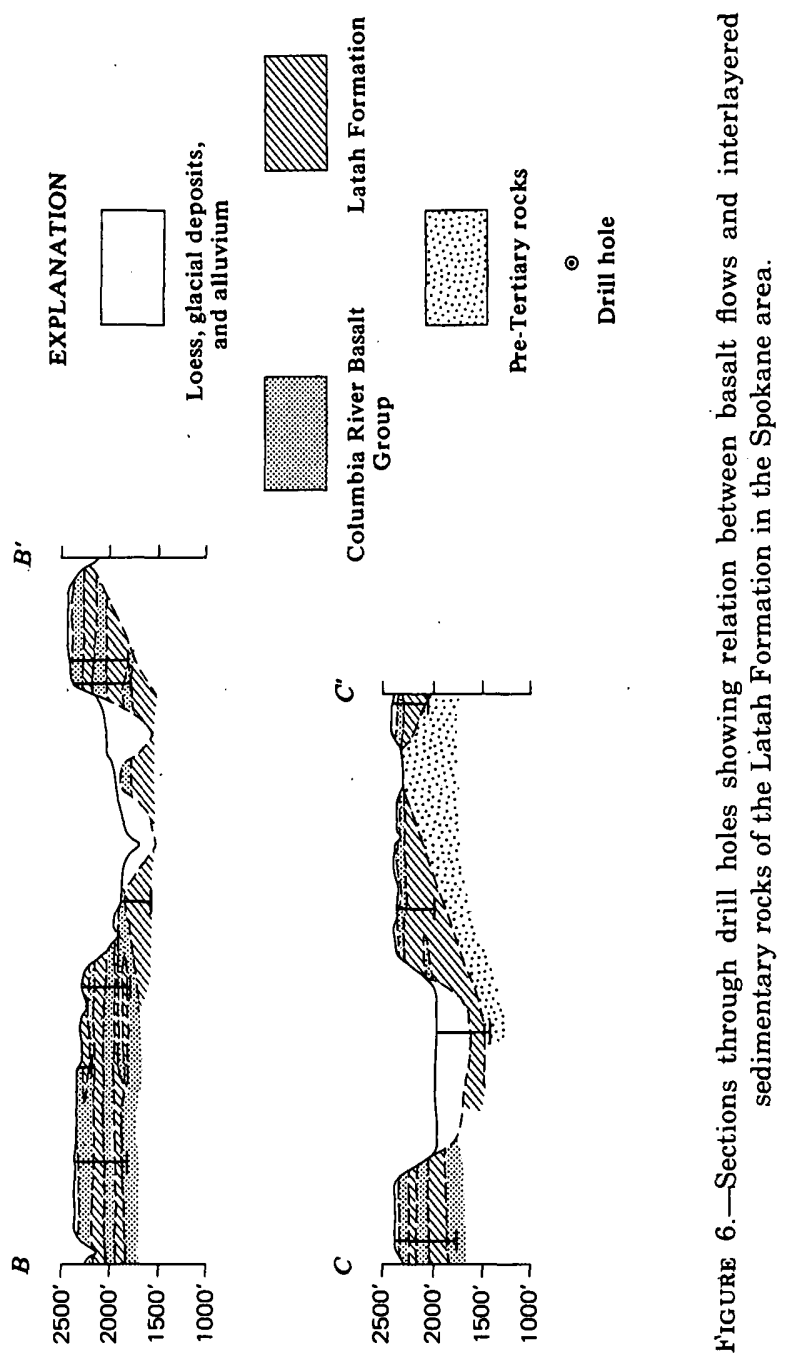


The large landslide areas in the Spokane quadrangle typically display a series of subdued elongate ridges nearly parallel to the source bluff or cliff. These ridges step down successively toward the toe of the slide and are the upper surfaces of successive blocks or wedges that have calved off the former cliff. These relations suggest that some slides resulted from multiple failure that took place in several episodes. A rotation counter to their direction of movement is evident for some of these blocks, as small closed depressions or basins have been formed behind them. One of the larger of these basins below the northwest edge of Orchard Bluff contains a small lake over $1,000 \mathrm{ft}$ $(300 \mathrm{~m})$ long. The material in the toes of many slides has moved thousands of feet horizontally from its original position, even though the total vertical relief of the headwall amounts to only $400-500 \mathrm{ft}$ $(120-150 \mathrm{~m})$.

The makeup and relations of a slide to its surroundings are well exposed near the mouth of Deep Creek about $10 \mathrm{mi}(16 \mathrm{~km})$ northwest of Spokane. Here the stream has eroded down into the toe of the slide and also about $50 \mathrm{ft}(15 \mathrm{~m})$ into the glaciofluvial sand and gravel that surrounds and partly covers this part of the slide. For almost half a mile $(1 \mathrm{~km})$ the stream course is an intricate maze around and under very large basalt blocks, some $25 \mathrm{ft}(8 \mathrm{~m})$ across or even larger. Immediately adjacent and upstream from this section, poorly indurated undisturbed claystone and siltstone of the Latah Formation are exposed for as much as $40 \mathrm{ft}(12 \mathrm{~km})$ above the west side of the creek and for several hundred feet (about $100 \mathrm{~m}$ ) along its course. Failure of these weak sedimentary rocks triggered the slide, and they acted as a lubricant to facilitate the movement. Directly overlying the Latah is a jumbled mass of broken basalt blocks of all sizes mixed with sediments. Part of the basalt has come from a pillow-palagonite complex. Broken and bent trees on top of the slide material show that some movement has occurred recently. The present stream erosion has reactivated the slide, and as long as this erosion continues, some movement will occur from time to time.

All the landslides involving. interlayered sediments and basalt flows appear to have had a history similar to the slide at Deep Creek. Failure occurred within a relatively weak sedimentary layer, or at the soil interface between the pre-Tertiary bedrock and the pile of sedimentary rock and basalt. The break did not occur until the valley wall had been steepened to a critical angle, which for some places is apparently almost vertical. In addition the slide may not have been triggered until the rocks were highly saturated with water.

Except for the slide at Deep Creek, all the slides now appear to have been stabilized. No fresh breaks were noted, nor any tilted or uprooted trees observed on any of the others. The lower parts of the 
slides west and north of Spokane have been covered or partly buried by debris deposited during the later glacial episodes. Some are veneered by glacial deposits dating back to some of the earlier glacial episodes. Thus they appear to have come into being during interglacial erosion and are late Pleistocene in age. Those in the vicinity of St. Maries are probably also of similar age but are buttressed by normal alluvial fill rather than by glacial debris.

On the basis of what can be observed, all these landslides probably will continue to remain dormant unless their equilibrium is disturbed by stream undercutting or manmade excavations.

\section{REFERENCES CITED}

Anderson, A. L., 1940, Geology and metalliferous deposits of Kootenai County, Idaho: Idaho Bur. Mines and Geology Pamph. 53, $67 \mathrm{p}$.

Berry, E. W., 1929, A revision of the flora of the Latah Formation: U.S. Geol. Survey Prof. Paper 154-H, p. 222-265.

Bingham, J. W., 1970, Several probable source vents for the Roza and Priest Rapids type basalts in Whitman and Adams Counties, Washington: Columbia River Basalt Symposium, 2d, Cheney, Wash., 1969, Proc., p. 171-172.

Bingham, J. W., and Grolier, M. J., 1966, The Yakima Basalt and Ellensburg Formation of south-central Washington: U.S. Geol. Survey Bull. 1224-G, 15 p.

Bingham, J. W., and Walters, K. L., 1965, Stratigraphy of the upper part of the Yakima Basalt in Whitman and eastern Franklin Counties, Washington: U.S. Geol. Survey Prof. Paper 525-C, p. C82-C90.

Bishop, D. T., 1969, Stratigraphy and distribution of basalt, Benewah Co., Idaho: Idaho Bur. Mines and Geology Pamph. 140, 20 p.

Bond, J. G., 1963, Geology of the Clearwater embayment: Idaho Bur. Mines and Geology Pamph. 128, $83 \mathrm{p}$.

Bretz, J. H., 1959, Washington's channeled scabland: Washington Div. Mines and Geology Bull. 45, $57 \mathrm{p}$.

Brock, M. R., and Grolier, M. J., 1973, Chemical analyses of basalt samples from the Columbia Plateau, Washington, Oregon and Idaho: U.S. Geol. Survey open-file report, $35 \mathrm{p}$.

Brown, R. E., 1970, Some suggested rates of deformation of the basalts in the Pasco Basin and their implications: Columbia River Basalt Symposium, 2d, Cheney, Wash., 1969, Proc., p. 179-187.

Brown, R. W., 1937, Additions to some fossil floras of the western United States: U.S. Geol. Survey Prof. Paper 186-J, p. 163-206.

Chaney, R. W., and Axelrod, D. I., 1959, Miocene floras of the Columbia Plateau: Carnegie Inst. Washington Pub. 617, 224 p.

Dort, Wakefield, Jr., 1967, Late Cenozoic volcanism, St. Joe Valley, Idaho: Northwest Sci. v. 41 , no. 4 , p. 141-151.

Evernden, J. F., and James, G. T., 1964, Potassium-argon dates and the Tertiary flora of North America: Am. Jour. Sci., v. 262, p. 945-974.

Foxworthy, B. L., and Washburn, R. L., 1963, Ground water in the Pullman area, Whitman County, Washington: U.S. Geol. Survey Water-Supply Paper 1655, 71 p.

Fuller, R. E., 1931, The aqueous chilling of basaltic lava on the Columbia River Plateau: Am. Jour. Sci., 5th ser., v. 21, p. 281-300.

Gray, Jane, and Kittleman, L. R., 1967, Geochronometry of the Columbia River basalt 
and associated floras of eastern Washington and western Idaho: Am. Jour. Sci., v. 265, p. 257-291.

Griggs, A. B., 1973, Geologic map of the Spokane quadrangle, Washington, Idaho, and Montana: U.S. Geol. Survey Misc. Geol. Inv. Map I-768.

Grolier, M. J., and Bingham, J. W., 1971, Geologic map and sections of parts of Grant, Adams, and Franklin Counties, Washington: U.S. Geol. Survey Misc. Geol. Inv. Map. I-589.

Hobbs, S. W., Griggs, A. B., Wallace, R. E., and Campbell, A. B., 1965, Geology of the Coeur d'Alene district, Shoshone County, Idaho: U.S. Geol. Survey Prof. Paper $478,139 \mathrm{p}$.

Holmgren, D. A., 1970, K/Ar dates and paleomagnetics of the type Yakima Basalt, central Washington: Columbia River Basalt Symposium, 2d, Cheney, Wash., 1969, Proc., p. 189-200.

Hosterman, J. W., 1969, Clay deposits of Spokane County, Washington: U.S. Geol. Survey Bull. 1270, $96 \mathrm{p}$.

Hosterman, J. W., Scheid, V. E., Allen, V. T., and Sohn, I. G., 1960, Investigation of some clay deposits in Washington and Idaho: U.S. Geol. Survey Bull. 1091, 147 p.

Kirkham, V. R. D., 1926, Groundwater for municipal supply at St. Maries, Idaho: Idaho Bur. Mines and Geology Pamph. 17, 12 p.

Kirkham, V. R. D., and Johnson, M. M., 1929, The Latah Formation in Idaho: Jour. Geology, v. 38, p. 483-504.

Knowlton, F. H., 1926, Flora of the Latah Formation of Spokane, Washington, and Coeur d'Alene, Idaho: U.S. Geol. Survey Prof. Paper 140-A, p. 17-81.

Lindgren, Waldemar, 1900, The gold and silver veins of the Silver City, De Lamar and other mining districts in Idaho: U.S. Geol. Survey 20th Ann. Report, pt. III, p. 65-256.

1901, The gold belt of the Blue Mountains of Oregon: U.S. Geol. Survey Ann. Report, pt. II, p. 551-776.

Mackin, J. H., 1961, A stratigraphic section in the Yakima Basalt and Ellensburg Formation in south-central Washington: Washington Div. Mines and Geology Rept. Inv. 19, $45 \mathrm{p}$.

Moore, J. G., Phillips, R. L., Grigg, R. W., Peterson, D. W., and Swanson, D. A., 1973, Flow of lava into the sea, 1969-1971, Kilauea Volcano, Hawaii: Geol. Soc. America Bull., v. 84, p. 537-546.

Newcomb, R. C., 1970, The Columbia River Group; its tectonic structure in Washington, Oregon, and Idaho: Columbia River Basalt Symposium, 2d, Cheney, Wash., 1969, Proc., p. 173-175.

Pardee, J. T., 1911, Geology and mineralization of the upper St. Joe River basin, Idaho: U.S. Geol. Survey Bull. 470, p. 39-71.

Pardee, J. T., and Bryan, Kirk, 1926, Geology of the Latah Formation in relation to the lavas of the Columbia Plateau near Spokane, Washington: U.S. Geol. Survey Prof. Paper 140-A, $17 \mathrm{p}$.

Ringe, Don, 1970, Sub-loess basalt topography in the Palouse Hills, southeastern, Washington: Geol. Soc. America Bull., v. 81, p. 3049-3060.

Russell, I. C., 1893, A geological reconnaissance in central Washington: U.S. Geol. Survey Bull. 108, 108 p.

1901, Geology and water resources of Nez Perce County, Idaho: U.S. Geol. Survey Water-Supply Paper 53 and 54, pts. I and II, 141 p.

Schmincke, Hans-Ulrich, 1967a, Stratigraphy and petrography of four upper Yakima Basalt flows in south-central Washington: Geol. Soc. America Bull., 78, p. 13851442 .

1967b, Fused tuffs and pépérites in south-central Washington: Geol. Soc. America Bull., v. 78, p. 319-330. 
Shapiro, L., and Brannock, W. W., 1962, Rapid analysis of silicate, carbonate and phosphate rocks: U.S. Geol. Survey Bull. 1144-A, 56 p.

Snavely, P. D., Jr., MacLeod, N. S., and Wagner, H. C., 1973, Miocene tholeiitic basalt of coastal Oregon and Washington and their relations to coeval basalt of the Columbia Plateau: Geol. Soc. America Bull., v. 84, p. 387-424.

Swanson, D. A., and Wright, T. L., 1973, Extent, source and structure of the Roza Member of the Yakima Basalt in southeast Washington: Geol. Soc. America Abs. with Programs, v. 5, no. 1, p. 113-114.

Taubeneck, W. H., 1970, Dikes of Columbia River Basalt in northeastern Oregon, western Idaho, and southeastern Washington: Columbia River Basalt Symposium, 2d, Cheney, Wash., 1969, Proc., p. 73-96.

Thayer, T. P., and Brown, C. E., 1966, Geologic map of the Aldrich Mountain quadrangle, Grant County, Oregon: U.S. Geol. Survey Geol. Quad. Map GQ-438, scale $1: 62,500$.

Trimble, D. E., 1950, Joint-controlled channeling in the Columbia River basalts: Northwest Science, v. 24, no. 1, p. 85-88.

Umpleby, J. B., and Jones, E. L., 1923, Geology and ore deposits of Shoshone County, Idaho: U.S. Geol. Survey Bull. 732, 156 p.

Wagner, W. R., 1949, The geology of the south slope of the St. Joe Mountains, Shoshone County, Idaho: Idaho Bur. Mines and Geology Pamph. 82, 48 p.

Waters, A. C., 1960, Determining direction of flow in basalts: Am. Jour. Sci., v. 258-A, (Bradley volume) p. 350-366.

-1961, Stratigraphic and lithologic variations in the Columbia River basalt: Am. Jour. Sci., v. 259, p. 583-611.

Watkins, N. D., and Baksi, A. K., 1974, Magnetostratigraphy and oroclinal folding of the Columbia River, Steens, and Owyhee basalts in Oregon, Washington, and Idaho: Am. Jour. Sci., v. 274, p. 148-189.

Weis, P. L., 1968, Geologic map of the Greenacres quadrangle, Washington: U.S. Geol. Survey Geol. Quad. Map GQ-734, scale 1:62,500.

Wright, T. L., Grolier, M. J., and Swanson, D. A., 1973, Chemical variation related to the stratigraphy of the Columbia River Basalt: Geol. Soc. America Bull., v. 84, p. 371-386. 